\title{
The basic income: Initiating the needed discussion in industrial, work, and organizational psychology
}

\author{
Joachim Hüffmeier ${ }^{1 \star}$ and Hannes Zacher ${ }^{2}$ \\ ${ }^{1}$ Institute of Psychology, TU Dortmund University, Dortmund, Germany and ${ }^{2}$ Institute of Psychology-Wilhelm Wundt, \\ Leipzig University, Leipzig, Germany \\ ${ }^{\star}$ Corresponding author. Email: joachim.hüffmeier@tu-dortmund.de
}

(Received 4 October 2019; revised 10 August 2020; accepted 15 August 2020)

\begin{abstract}
The basic income (BI) involves regular and unconditional cash payments to all members of a political community, without the requirement or expectation to work in return. Whereas the BI is increasingly discussed by political parties, organizational practitioners, and in other academic disciplines, the field of industrial, work, and organizational (IWO) psychology has so far remained silent on the concept. In this article, we first explain why there is a growing interest in the BI and outline potential reasons why the BI, despite its topical relevance, has not been discussed by IWO psychologists. Next, to initiate the needed discussion on the $\mathrm{BI}$, we outline the most important background information on the concept, including its definition, history, financial aspects, main criticisms, and potential advantages. We further provide first answers to common questions about the BI from an IWO psychology perspective, such as "(Why) would people still work if they received a BI?" We conclude with a discussion of potential positive and negative consequences of the BI as well implications for future theory development, empirical research, and practical applications.
\end{abstract}

Keywords: Basic income; lottery question; meaning of work; pay; work design

\begin{abstract}
A basic income gives people an option-to exit the labor market, to relocate to a more competitive market, to invest in training, to take an entrepreneurial risk, and so on. And the existence of that option allows them to escape subjection to the will of others. It enables them to say "no" to proposals that only extreme desperation would ever drive them to accept. It allows them to govern their lives according to their own plans, their own goals, and their own desires. It enables them to be free. (Zwolinski, 2013)
\end{abstract}

Moreover, the proposal goes against a widely accepted notion of justice: it is unfair for ablebodied people to live off the labor of others. Most workers would, correctly in my opinion, see the proposal as a recipe for exploitation of the industrious by the lazy. (Elster, 1986, p. 719)

An idea has recently begun to gain traction. Switzerland had a plebiscite about it in 2016 and, even in this conservative country, $23 \%$ of citizens voted for it (www.grundeinkommen.ch). In Kenya, the idea has been implemented in 2016 in several villages for at least a 10-year time span (Give Directly, 2018), and the results are currently pending. In the Namibian area of OtjiveroOmitara, a 2-year trial was conducted from 2008 to 2009 with promising results (e.g., more economic activity; less hunger, poverty, and child malnutrition; higher school attendance; and 
less crime; Haarmann \& Haarmann, 2012). ${ }^{1}$ In a large survey on the idea, 10,000 citizens were surveyed in 28 European countries. Overall, $64 \%$ of respondents indicated that they would vote for its introduction in a referendum (Holmes, 2016). In another survey with more than 40,000 citizens from 23 European countries, about 56\% were in favor of realizing this idea in their country, although considerable variability between countries existed (Roosma \& van Oorschot, 2020). On a global scale, it was repeatedly discussed at the World Economic Forum, 2018). Although the idea has not been implemented anywhere countrywide and outside of test trials, it is not unrealistic that a first country will introduce it in the foreseeable future.

This idea is the basic income (BI; Cole 1953; Tinbergen, 1956), often also termed universal basic income or unconditional basic income. The BI is commonly defined as "a periodic cash payment unconditionally delivered to all on an individual basis, without means-test or work requirement" (https://basicincome.org/basic-income/). ${ }^{2}$ Thus, a political community would provide a regular and unconditional cash payment to all of its members individually as opposed to households or families-although BI proposals differ as to whether children should obtain a BI or not (see Ortiz et al., 2018, for an overview). There would be neither any means testing (i.e., financial neediness is not a criterion) nor prior payments to the social welfare system (e.g., unlike unemployment insurance) or an expectation or even obligation to do anything in return (i.e., no work requirement; Vanderborght \& Van Parijs, 2005; Van Parijs \& Vanderborght, 2017).

The BI plebiscites, polls, and trials mentioned above have been accompanied by intense media coverage as well as public and private discussions. The BI also draws immense political and entrepreneurial interest. For instance, Andrew Yang, a former democratic presidential candidate for the upcoming U.S. election, promised to implement a BI of $\$ 1,000$ a month per adult if he was elected (see www.yang2020.com). Bernie Sanders, another democratic candidate, repeatedly talked favorably about it, and Hillary Clinton pondered including the BI in her 2016 election campaign (Clinton, 2017). In Germany, there is a political party exclusively devoted to promoting the BI ("Bündnis Grundeinkommen," meaning Basic Income Alliance), and all major political parties are discussing it. Test trials are currently planned in California as well as Brazil, Germany, the Netherlands, India, and other countries. Finally, prominent entrepreneurs and CEOs like Bill Gates (founder of Microsoft), Elon Musk (Tesla, Space X), Mark Zuckerberg and Chris Hughes (co-founders of Facebook), and Götz Werner (founder of the German drugstore chain DM) have expressed interest in the BI and/or actively support it (e.g., Werner, 2018).

The intense public interest in the BI is mirrored by a lively academic discourse on the BI in many disciplines such as business (e.g., Nooteboom, 1987), economics (e.g., Hum \& Simpson, 1993; Jackson, 1999), history (e.g., Cunliffe \& Erreygers, 2001; King \& Marangos, 2006), philosophy (e.g., Barry, 1996; Quinn, 1994), political sciences (e.g., De Wispelaere, 2016; Jordan, 2011), and sociology (e.g., Healy et al., 2013; McKay \& Vanevery, 2000). However, there has hardly been any resonance related to the BI in psychology. This lack of interest, especially in industrial, work, and organizational (IWO) psychology, is surprising, because many important questions regarding the BI are genuinely psychological in nature. Some of the questions that are typically asked are:

\footnotetext{
${ }^{1}$ There are further studies often mentioned in this discussion that are, however, not "pure" implementations of the idea. A prominent example of these studies is the recent experiment in Finland that took place from 2017 to 2018. Because this study was implemented exclusively among unemployed people, it is not pertinent to the current article. We, thus, refrain from reporting results of this and other related studies.

${ }^{2}$ There are various terms for the BI beyond unconditional basic income and universal basic income, many of them in the mother tongue of their respective advocates (for an overview, see Vanderborght \& Van Parijs, 2005, p. 14). Such terms are, for instance, dividende territorial (Charlier, 1893), state bonus (Milner \& Milner, 1918), national dividend (Douglas, 1924), basisinkomen (Tinbergen, 1956), demogrant (Tobin et al., 1967), allocation universelle (Collectif, Fourier, 1985), or bürgergeld (Mitschke, 1985). We use the term basic income in the current article because it is widely used in the scientific literature (see, for instance, the Basic Income Earth Network [BIEN]).
} 
- Will people continue to work for pay if they receive a BI?

- Which factors contribute to people's experience of work satisfaction and meaningfulness?

- If people continue to work, how exactly will they go about it? Will they remain in their current position or will they change jobs, organizations, or even occupations?

- How many will stop working, and what are the most likely psychological consequences of their voluntary unemployment?

- Will current working conditions have to change and, if yes, in which ways?

- Will more people become entrepreneurs, homemakers, caregivers, or volunteers?

- How would the BI influence workers' perceptions of fairness?

We believe that the BI is a topic of high relevance to the IWO psychology community, and, therefore, we intend to initiate the hitherto lacking psychological discussion on the BI with this focal article. We thereby contribute to research and practice in IWO psychology in three ways. First, we outline important background information to put the needed discussion of the BI among psychological scientists and practitioners on a solid knowledge base-a discussion that is highly relevant for both groups but has not yet begun. At the moment, psychological scientists miss the chance to inform an ongoing interdisciplinary debate with relevant, state-of-the-art psychological knowledge, and by not participating they also fail to benefit from this discussion. Moreover, psychologists miss the opportunity to further develop their theories on a number of topics (e.g., on the role of work in people's lives, on changes in experience and behavior in the workplace when employees become less dependent on their employers, and when power asymmetries are alleviated). For psychological practitioners, the absence of a debate may even be harmful because the likely consequences of the implementation of a BI (e.g., more part-time work, less organizational commitment, more fluctuation) will strongly affect the work of many psychologists, for instance, in human resources departments and in consulting firms.

Second, we provide (first) answers to the above questions on the BI from an IWO psychology perspective. These questions are often the subject of heated public debates, although the relevant psychological knowledge is quite clear. By differentiating between the questions for which we have at least some tentative theory- and evidence-based answers and the questions for which we currently do not have sufficient psychological knowledge, we hope to contribute to a more balanced and pertinent discussion. Perhaps future discussions on the BI can then also focus more strongly on the pressing and actually contentious questions (e.g., how to finance the BI).

Third, we also highlight and discuss a number of potential positive and negative consequences of the BI that have not been sufficiently considered in the ongoing debate (e.g., changes in participation patterns in paid work, shrinking organizational innovation). We thereby contribute to a more complete, balanced, and differentiated perspective on the BI, and we emphasize that the BI is an idea with great potential to solve important societal challenges but also with a number of disadvantages that should be seriously considered.

In contrast, it is beyond the scope of this article to contribute to the further conceptual development of the BI. We can also not provide an in-depth discussion of the advantages and disadvantages of various specific BI proposals, and we do not intend to make new contributions to the ongoing discussion of how a BI could be financed. We will, however, point out the current state of the debate related to these issues and direct the readers to relevant resources.

\section{Why is there a growing interest in the BI?}

The BI appears to strike a chord with many individuals and groups and for many reasons. In the following, we discuss five factors that make the BI appealing. The first factor is the discussion about the consequences that digitization, automatization, and computerization may have for overall employment. This is by no means a new discussion (see, for instance, the Ad Hoc Committee 
on the Triple Revolution, 1964; Keynes, 1930/2010). In fact, research has shown that work hours per capita have been shrinking massively from the 19th century onward (Schildt, 2006). This shrinkage occurred in the course of the industrialization and is due to rationalization efforts and the ever-increasing use of machines, computers, and robots. However, the imminent wave of digitization, automatization, and computerization will probably not only reduce available paid work (i.e., technological unemployment) but may also eradicate entire classes of blue-collar jobs (e.g., truck drivers, warehousemen, cashiers). Such consequences are also expected to extend to white-collar jobs such as legal assistants, pharmacists, medical diagnosticians, stockbrokers (see Lowrey, 2018), or human resource managers (when certain steps of the personnel selection process are done by machines). It is predicted that millions of jobs will be replaced and may be lost for good in the course of these developments. Although some predictions are rather optimistic (e.g., World Economic Forum, 2018), others anticipate a high level of technological unemployment (e.g., a controversial prognosis saw about half of U.S. jobs as threatened by technological advances, see Frey \& Osborne, 2013; see also Brynjolfsson \& McAfee, 2014). Many people believe that the BI could be an effective response to the threat of technological mass unemployment. This is because the BI could help people who lost their jobs due to technological advancements meet their basic needs and it might also support them in undertaking new work activities while having a minimum financial security.

A second factor driving the interest in the BI concerns its potential as a solution to already existing poverty and inequality. Although continued economic growth was the leading economic and political doctrine for a long time, it has not been able to eradicate unemployment (at times and in various places of the world not even mass unemployment). Thus, poverty and economic inequality are and remain important contemporary problems in Western countries-even before the expected wave of technological unemployment will hit (Brynjolfsson \& McAfee, 2014; Frey \& Osborne, 2013). Many people lack relevant and up-to-date occupational competencies and have been unemployed for several years. They will probably not be able to reenter the labor market under current conditions, with increasingly complex demands and highly specialized tasks. However, at least in Western economies, there are different social welfare instruments to target existing poverty and economic inequality. These instruments typically involve an application procedure and rely on means testing (e.g., availability of financial support from relatives). Both aspects may result in feared or actual stigmatization and possibly bring about negative emotions like shame or guilt in people applying for these benefits, which may prevent them from applying in the first place (i.e., resulting in a relatively low take-up rate). In contrast, a BI would be paid automatically and without means testing to all citizens (i.e., there would be no need to apply for it and no need to disclose one's private financial situation in the process). Thus, a BI could be more effective in fighting poverty and inequality than existing means-tested social benefits (e.g., Standing, 2017; Torry, 2016; Van Parijs \& Vanderborght, 2017).

A third factor that makes the BI interesting also focuses on social justice aspects. It goes back to the early and very basic idea that the world and its natural resources are a common good and, thus, belong to all people (e.g., Ambrose, 1927; Vives, 1526/2010). Thus, earnings resulting from the use of worldly resources should be distributed, which could be realized with a BI as a regular dividend to all citizens (see Paine, 1796, for a very early suggestion). Although this idea appeals to many people, it has rarely been realized. However, there is one prominent example of such a redistribution of the earnings from collective resources: Since 1982, the state of Alaska pays its citizens a yearly dividend to let them participate in the earnings that are generated from the exploitation of Alaska's immense oil resources.

It is this central notion underlying the BI-the world as a common good and the according obligation to distribute the revenues from its use to all people-that differentiates the BI from other widely discussed and implemented income-redistribution measures such as, for instance, the living wage. Rather than drawing on a philosophical justification and separating work and income, the living wage is awarded for concrete efforts to engage in paid work. It is designed 
to fulfill the central human right of a "just and favourable remuneration" that ensures "an existence worthy of human dignity" (Article 23 of the United Nations Universal Declaration of Human Rights, 1948).

A fourth factor increasing the interest in the BI concerns a deep-rooted dissatisfaction with different facets of today's working world. Many people want to work differently than they currently do. For instance, they would prefer to work fewer hours even if their salary shrank accordingly (e.g., about half of employees working full-time in Western Europe; Brauner et al., 2018; Fagan \& Warren, 2001). However, under current conditions, most employees cannot reduce their working time according to their wishes. Relatedly, many people caring for frail relatives would like to have more discretion about their work schedules but are often not granted the desired flexibility (e.g., Brauner et al., 2018; Fagan \& Warren, 2001). Moreover, many people do not like certain aspects of their current work situation, which results in various problems: For instance, only about $15 \%$ of surveyed employees worldwide report being engaged with their work, and as many as $50 \%$ of the surveyed people were actively looking for new jobs (Gallup, 2017). Possible reasons for this state of affairs are that many people do not feel treated well by their leaders (Gallup, 2017) or do not perceive their jobs as meaningful (Cartwright \& Holmes, 2006). This lack of meaning is not restricted to "bullshit jobs" (i.e., jobs where even the holders know that their tasks are useless, pointless, unnecessary, and may even cause harm; Graeber, 2018), although these jobs may be primarily affected. A further hallmark of today's working world is that many employees are absent from work relatively often and retire far before reaching their regular or typical retirement age (i.e., 65-70 years). These phenomena are often traced back to the strain employees have to endure over their careers, but it may also partly result from perceived lack of meaning. It is the hope of many that a BI could contribute to changes that render the future world of work more humane because it would give people more choices, for instance to reject certain jobs, change jobs more easily, reduce working hours, or even alternate between phases of paid work and "only" unpaid work. This freedom would, thus, allow people to better integrate their private and working lives and force employers to offer better working conditions that make work less straining and more meaningful.

As a fifth factor, a BI could also positively affect existing gender inequalities. Although not reflected in the official labor statistics, a very large share of a society's work has traditionally been and is currently still done by women. This unpaid work (e.g., reproductive work including breastfeeding, household/caregiving work, and further forms of "hidden" work) by far exceeds paid work: In Germany, for instance, people spent 89 billion hours of unpaid work in 2013, whereas they "only" spent 66 billion hours of paid work (Destatis, 2016). Overall, 75\% of the unpaid work is done by women (McKinsey Global Institute, 2015), and the unequal shares of unpaid work done by women and men are universal across countries (Miranda, 2011). If women also engage in paid work, this results in a "double shift" for them. In any case, because women do much more of the unpaid work than men, many of them financially depend on their partner. Accordingly, many people hope that a BI could better reward traditionally unpaid work activities and, thereby, empower women (e.g., Goehler, 2017; Schulz, 2017). In the words of Van Parijs and Vanderborght (2017, p. 186), "a basic income makes it easier to opt for part-time work and take career breaks. It thereby enables in particular poorly-paid women to escape from the double shift and an unbearable life pace." However, there is also a critical perspective on the BI with respect to gender equality. Some feminists worry that a BI may reinforce traditional gender roles and cement the current division of labor (e.g., Orloff, 2013; Robeyns, 2001).

\section{Why the BI has not been a topic in IWO psychology thus far}

Whereas the BI has drawn interest from various academic disciplines, a discussion in the field of psychology, and especially in IWO psychology, is currently lacking. Here, we outline a few 
possible reasons. First, the BI and its consequences are currently very difficult to study empirically, making the BI a challenging topic for IWO psychologists. Even small-scale BI test trials would incur immense financial costs, and related studies would be very difficult to realize. Moreover, there is a mismatch between (short-term) experimentation-as the preferred method within psychology — and the methods required to study the BI's longer term consequences.

Second, studying the consequences of a BI needs a theoretical lens with a different resolution than is typically used in psychology: Most empirical research in IWO psychology has focused on individuals or small groups (i.e., a micro perspective), and it has been criticized for this limited perspective (Bal \& Doci, 2018), which neglects larger scale influences on individuals. Moreover, IWO psychology has also been criticized for not considering the societal-level consequences of its work (Lefkowitz, 2017). Studying the consequences of a BI would broaden IWO psychology's focus and (also) require a meso and macro perspective to fully understand the multifaceted effects that may occur with a BI.

Third, IWO psychology typically focuses on studying extant interventions rather than theorizing about new or even "utopian" ideas like the BI. Recent measures that were studied in psychology after their implementation comprise, for instance, mothers' and fathers' extended possibilities for parental leave (e.g., Hideg et al., 2018; Horvath et al., 2018), organizational diversity training (Bezrukova et al., 2016), or antidiscrimination policies in the work context (Hebl et al., 2016).

Fourth and finally, like many other disciplines, psychology suffers from a science-practitioner gap. It often takes considerable time until interesting and relevant topics are investigated in IWO psychology, although they are (sometimes intensely) discussed in the relevant practitioner communities (Aguinis \& Cascio, 2008). Such a time lag may also have prevented a debate on the BI in psychology, and in IWO psychology in particular.

\section{History, definition, financial aspects, and main criticisms of the $\mathrm{BI}$}

In this section, we give an overview of the history and philosophical legitimization of the BI, its defining elements, costs of and financing options, advantages, and main criticisms. Van Parijs and Vanderborght (2017) as well as Ortiz et al. (2018) provide excellent overviews of these aspects, and we draw heavily from these resources in this section.

\section{A short history and legitimization of the BI}

The history of the BI can be clearly traced back at least to Thomas Paine (1796). Earlier precursors of and important arguments for the general BI idea were formulated by Thomas More (1516/ 1978) and Johannes Vives (1526/2010). However, there may even be earlier precursors of the BI: For instance, a law passed in ancient Rome determined that each Roman citizen above the age of 10 was entitled to 70 pounds of grain - as a measure to share the wealth of the prosperous Roman Empire (see Aldrete, 2004). In the fourth century after the birth of Christ, Saint Ambrose formulated an important principle, which was afterward repeatedly invoked in the history of the BI: the earth as "the common property of mankind" (Van Parijs \& Vanderborght, 2017, p. 71; see Ambrose, 1927). ${ }^{3}$ Two centuries later, a guaranteed income was apparently paid to all men, women, and children in a region of today's Pakistan under Caliph Abu Bakr (see Clark, 1986).

In his "De Subventione Pauperum," Vives (1526/2010) formulated a first philosophical legitimization of why municipal authorities should take care of the poor. He echoed Saint Ambrose's conviction that the earth is the property of mankind ${ }^{4}$ and focused on the Christian-Jewish duty of

\footnotetext{
3"The earth has been created in common for all, rich and poor: why do you claim for yourselves the right to own land?" (Ambrose, 1927, p. 47).

4"He has put everything which He has brought into existence into the great realm of the world, without barriers or locks, so that they can be common to all He has created" (Vives, 1526/2010, p. 46).
} 
charity. He argued that if the public (i.e., municipal authorities) took care of the poor, it would do so much more efficiently than private donors could (which was common practice at that time). However, he linked the receipt of public benefits with an obligation to work and, thus, deviated from the later idea of a BI, which is designed to be obligation free.

In his "Agrarian Justice," Paine (1796) was the first to clearly articulate the idea of a BI. In this book, he already covered most of the essential BI features. Drawing from the general conviction that the earth and its natural resources are the property of all, he derived a right for each citizen to obtain public benefits. Specifically, Paine (1796) suggested to

$[C]$ reate a national fund, out of which there shall be paid to every person, when arrived at the age of twenty-one years, the sum of fifteen pounds sterling, as a compensation in part, for the loss of his or her inheritance, by the introduction of the system of landed property. And also, the sum of ten pounds per annum, during life, to every person now living, of the age of fifty years, and to all others as they shall arrive at that age. (p. 612)

According to Paine, the proposed national fund should be financed by a "ground-rent" (Paine, 1796, p. 617) that each landowner would be obliged to pay to their community. In his "The Rights of Infants," Thomas Spence (1797) replied to Paine's Agrarian Justice and developed the BI idea further. He argued that every citizen has the right to obtain lifelong benefits, including everyone "from a day old to the extremest age" (Spence, 1797, p. 87).

Many theorists subsequently further refined the BI idea. Among the early and most outspoken and vivid supporters of the idea were Charles Fourier (1836/1967), Joseph Charlier (1848), and John Stuart Mill (1848). It was, however, not until the end of World War I that the idea was discussed more broadly. Bertrand Russell (1918) supported the BI idea before it became influential enough to be discussed in the political arena. This was facilitated by books by Denis Milner (1920; he and his wife Mabel termed the idea "state bonus," Milner \& Milner, 1918), and political discussions in Great Britain and Canada ensued. The BI idea was also discussed in other countries, for instance, in the United States (Bellamy, 1888/1983), Austria (Popper-Lynkeus, 1912), and France (Duboin, 1932). Although the idea found a strong supporter in the political arena in the US in Democratic Senator Huey Long (1934), it did not manage to get the necessary political support to be introduced during the interwar times.

Following World War II, there were high-profile debates on the BI in the US with contributions from presidential advisor Robert Theobald (e.g., 1961). He recommended that President Johnson's administration should guarantee an adequate income to all citizens as an answer to the "cybernation revolution" (i.e., the ever-growing automatization and rationalization efforts; see the Ad Hoc Committee on the Triple Revolution, 1964). Further, prominent economists like Friedrich Hayek (e.g., 1944), James Tobin (e.g., 1966), or John Kenneth Galbraith (1969) also supported the BI idea, whereas Milton Friedman (1962) developed a somewhat similar proposal (i.e., the negative income tax). ${ }^{5}$ The influence of the BI was, however, not restricted to academia, as, for instance, even Martin Luther King Jr. (1967) actively advocated for it. Although a presidential candidate from the Democratic Party, Senator George McGovern, temporarily included a BI proposal in his platform (McGovern \& Leontief, 1972), the BI did not become a reality in the US. However, the increasing public interest in social interventions targeting poverty like the BI led to four large-scale experiments from 1968 to 1980 in the US. These experiments did, however, study

\footnotetext{
${ }^{5}$ The negative income tax (NIT) is a tax credit paid to a household depending on the amount of its income in an expired fiscal year. Some, but not all NIT proposals contain an obligation to work. In terms of required financial resources, it can be designed to be equivalent to the BI. Whereas the BI would be paid upfront (e.g., at the beginning of each month), the NIT is paid after the closing of the fiscal year. Even if people were offered the option to receive the NIT at the beginning of a fiscal year (as an advance payment option), a relatively low take up rate could be expected (i.e., due to the necessity to initiate an application and due to [feared] stigmatization, shame, or guilt).
} 
negative income tax schemes (Friedman, 1962) rather than the BI (see the following section for a discussion on the results).

In the rest of the world, the BI discussion picked up rather slowly following World War II. However, in the 1970s, the discussion again gained traction with contributions, for instance, from Great Britain (Jordan, 1973), the Netherlands (Kuiper, 1975), Denmark (Meyer et al., 1978), and Sweden (Adler-Karlsson, 1979). Although there was an extended public and political debate in the Netherlands, the BI again did not become a reality. From then on, the BI (re)surfaced in several countries in the political debate at different times, but a constant BI discussion was since then mainly initiated and maintained in a scientific network termed "Basic Income European Network" (BIEN; set up in 1986), which was renamed "Basic Income Earth Network" (BIEN) in 2004. This network explicitly refers to the roots presented above and particularly to the common ownership of the world as one of the main reasons why a BI would not just be a promising but also a just idea.

In summary, however, the BI has not become a permanent reality to date, although it has been discussed for a long time and in many countries. Following Van Parijs and Vanderborght (2017), this may be due to a specific, two-part constellation: first, the reluctance of influential stakeholders in many countries (i.e., labor unions; employers; most political parties including socialist, communist, and Christian-democratic parties, and [parts of the] public opinion) and, second, the less than unanimous support of those who would benefit most from the BI (i.e., the precariat and women).

\section{The defining elements of the $\mathrm{BI}$}

To illustrate the BI's potential and possible consequences, we elaborate on its defining components in the following. However, before doing so, we briefly discuss the concrete financial design of the BI. The suggested amount of money that a BI should entail depends on the political origin of the respective BI proposal. Whereas neoliberal protagonists propose a BI level far below the poverty line (e.g., Murray, 2008; see also Friedman, 1968), others propose a BI at the poverty line (e.g., $\$ 1,000$ per month for a single person in the US; see Stern, 2016). Still others suggest a BI somewhat above the poverty line (e.g., $€ 1,200$ for a single person in Germany [about $\$ 1,340$ ], see Werner, 2018; CHF 2,500 [\$2,460] for an adult in the 2016 Swiss plebiscite). A BI above the poverty line would be necessary to ensure that BI recipients can actively take part in the political, social, and cultural lives of their countries (Werner, 2018), and, if they decide to do so, exit the labor market (see the first introductory quote). BI proposals also differ with respect to the suggested payment for children. Some proposals entail that children should receive $25 \%$ (see the Swiss proposal) or $50 \%$ of the adult rate, whereas others do not differentiate between adults and children (for an overview, see Ortiz et al., 2018).

Thus, there are many very different BI proposals (Ortiz et al., 2018). In this article, we follow Van Parijs and Vanderborght's (2017) general proposal for a full BI. ${ }^{6}$ The authors suggest taking fiscal residence, or the duty to pay taxes in a given country (rather than permanent residence or citizenship), as the criterion that determines who is entitled to a $\mathrm{BI}^{7}{ }^{7}$ They further propose to set the $\mathrm{BI}$ at $25 \%$ of the gross domestic product (GDP) per capita. In terms of the resulting monthly cash payments for individual citizens in 2015, 25\% of the respective GDP would have meant

\footnotetext{
${ }^{6}$ Note that there are also suggestions for a partial BI. These suggestions emerged because it appears more likely that-as a first step - a partial BI receives the necessary political support to be introduced. It is, however, the hope that the introduction of a partial BI will eventually pave the way for a full BI (e.g., https://basicincome.org/basic-income/; Van Parijs \& Vanderborght, 2017).

${ }^{7}$ Fiscal residence would be the necessary and sufficient criterion for receiving the BI. It is not relevant whether people earned enough money so that they actually paid taxes in the past.
} 
$\$ 1,163$ in the US, $\$ 860$ in the United Kingdom, and $\$ 1,670$ in Switzerland (see Van Parijs \& Vanderborght, 2017, p. 11). ${ }^{8}$

In the following we assume, in accordance with the standards of the International Labour Organization, that the BI would not replace "main public social insurance and programmes for those with special needs" (Ortiz et al., 2018, p. x), although there are voices arguing for a replacement of all public transfers by the BI (e.g., Murray, 2008; Sennett, 2003). A BI designed in the way described here could, however, replace general social assistance and unemployment benefits without a loss of overall social welfare (see Ortiz et al., 2018).

\section{Arguments for paying the $\mathrm{Bl}$ in cash rather than in in-kind payments}

In accordance with the normative standard of "real freedom for all-and not just for the rich" (Van Parijs \& Vanderborght, 2017, p. 4), which is often invoked in the BI discourse, it would be consequent to let BI recipients freely decide how they want to spend their money (Bregman, 2017). However, there are also practical reasons why cash payments are preferred over in-kind transfers. For instance, a distribution of cash as compared with the distribution of goods like food, water, clothes, and housing is less bureaucratic due to the availability of relatively easy electronic transfers, is less prone to local illegitimate lobbying and partisan decision making, and is probably also more resource efficient (i.e., there would be less misallocation; for an overview on the advantages of cash payments, see Hanlon et al., 2010). Moreover, although there are widespread fears of misspending (see Lowrey, 2018), a systematic review on the effect of cash payments in low- and middle-income countries (Bastagli et al., 2016) showed that recipients of cash payments typically spent the money to provide for their own and their family's basic needs. They typically did not spend the money for luxuries, alcohol, tobacco, or other drugs (Bastagli et al., 2016; Evans \& Popova, 2014). Finally, the local economy is strengthened more by cash payments than by imported free goods (Bregman, 2017). Thus, there are strong arguments for paying the BI via cash payments and not via in-kind transfers.

\section{Arguments for paying the $\mathrm{BI}$ on an individual basis}

In many countries with developed welfare systems, social benefits like public assistance are typically paid to a household as a whole. Often, the payments per person in a household are proportionally reduced with the number of household members. This is because it is more expensive per capita to cover the basic costs of people living alone as compared with those living in a shared household. Such costs comprise, for instance, rent, basic equipment, furniture, or heating. Moreover, any financial resources that close relatives possess may additionally reduce the focal person's entitlement to the transfers (as is, for instance, the case in the German public assistance scheme for longer term unemployed people).

The BI would differ from this approach in two ways. First, it would be paid to all adult individuals in a household separately (and a possible BI for children would be paid to an individual adult member of the household, for instance the mother). Second, the financial resources of other household members would not play a role in determining the financial entitlement of a focal person, because each person-rich or poor-would be entitled to the same sum if a BI were in place. These two levels of individuality have a number of advantages (see also Van Parijs \& Vanderborght, 2017): For instance, paying money to each adult individually would especially benefit women, who are often still mainly responsible for the unpaid family and household work and, thus, have typically lower earnings than their partners or even no own earnings at all. This is an

\footnotetext{
${ }^{8}$ The BI should be stable across time. To achieve this, the BI could be linked to the GDP per capita (Milner, 1920; Stern, 2016). Other authors suggest linking it to the average GDP of several prior years to reduce extreme fluctuations (Van Parijs \& Vanderborght, 2017).
} 
important difference when comparing the BI with other income redistribution measures, such as the living wage. Living wages are exclusively awarded to those who do paid work.

Receiving an individual BI and, thus, being able to dispose of their own money, likely changes women's position in the family and gives them more power and more choices (Bastagli et al., 2016) because they would no longer depend entirely on their partners. Against the normative standard of "real freedom for all" (see Van Parijs \& Vanderborght, 2017), this change would obviously constitute a significant improvement as compared with the status quo. ${ }^{9}$

Reducing the entitlement to social benefits proportionately with the number of household members necessitates efforts to ascertain whether different people do in fact live alone or together in a shared household. The related administrative costs and the intrusions into privacy that are associated with these efforts are omitted when each person receives the same amount of money, irrespective of close others' financial resources. Moreover, this approach avoids the so-called "loneliness trap" (Van Parijs \& Vanderborght, 2017, p. 14): If social benefits are reduced proportionately with the number of household members, there is a financial incentive to live alone in individual households (or a financial punishment for cohabitation). If people have strong financial needs (i.e., with low overall levels of social benefits), this incentive may very well become effective. This is problematic because loneliness can have severe consequences, not least for individual wellbeing and health (e.g., Cacioppo \& Hawkley, 2009; Russell, 1996).

\section{Arguments for paying the $\mathrm{BI}$ without a means test}

In many countries, minimum-income schemes exist that are conditional (i.e., they involve a means test). In these schemes, the money transferred to those eligible is typically the difference between their earnings and the lowest socially accepted financial threshold in a country (e.g., the national poverty line). If, at some point, people have earnings that-together with their received social benefits-go beyond this threshold, their transfers are typically taken back one-to-one by public authorities: For each monetary unit they earn, an equivalent monetary unit from their transfers is deducted. This effective tax rate of $100 \%$ on labor income obviously does not motivate the pursuit of paid work.

This situation is aggravated by two additional concomitants: First, the jobs that are available to (long-term) recipients of social benefits are often insecure in terms of the possible extent and duration of the employment, unreliable in terms of (regular) pay, and precarious in terms of pay levels and working conditions. Second, following employment spells in such jobs, it takes administrative efforts and often considerable time to reestablish the entitlement to social benefits, given how social bureaucracies work (Hirsch, 2015; Piketty, 1999). Affected people may also perceive considerable uncertainty as to whether and when transfers may ultimately be reinstated. Thus, the risk of piling up debts in the time following employment spells in insecure jobs is real. Conditional minimum-income schemes can accordingly lead to many uncertainties among the recipients. Because people are typically motivated to have control and to avoid uncertainties, a factual exclusion from work may result (i.e., the so-called "unemployment trap").

By contrast, the BI is an unconditional minimum-income scheme, which does not involve a means test. Moreover, it is conceptualized as a benefit that "is not withdrawn or reduced but kept in full when people earn a low income" (Van Parijs \& Vanderborght, 2017, p. 19). In other words, the $\mathrm{BI}$ is, by design, not combined with an effective tax rate of $100 \%$ on labor income. It can be topped up with earnings - at least up to a certain amount-before such strong taxation sets in and, thus, provides a secure "floor on which all can stand, not just another, more sophisticated policy targeted at the poor" (Van Parijs \& Vanderborght, 2017, p. 39).

\footnotetext{
${ }^{9}$ Paying women for their hitherto unpaid work is not equivalent to implementing a BI because the assumed positive effect of a BI goes beyond the group of women. It should extend to other societal groups (e.g., the precariat or those who are currently about to lose their job due to technological advances).
} 
These aspects of a BI offer the following three advantages as compared with conditional minimum-income schemes (see Van Parijs \& Vanderborght, 2017). First, the take-up rate can be expected to be much higher for unconditional than for conditional minimum-income schemes. To obtain conditional benefits, poor people have to take active steps (i.e., initiate and traverse often quite complex application procedures). For different reasons (e.g., illiteracy, ignorance, [fear of] stigmatization, shame, guilt), many of them may not do so, although they would be in principal entitled to these benefits. Receiving an unconditional BI would not require active steps and also not imply stigmatization and negative self-conscious affect like shame or guilt. Second, because people remain entitled to the BI even if they are receiving an income, there should be less exclusion from work (less of an unemployment trap; see Hirsch, 2015). Because they would receive their monthly BI payment up front and could top it up with earnings from paid labor, people would have to fear less the uncertainties of insecure and precarious jobs (i.e., they could be less uncertainty avoidant), and they could more easily accept insecure work and thereby avoid the unemployment trap. Third, the additional money that people could earn-at least up to a certain point -would increase their net income because the BI is conceptualized in such a way that it can be fully kept and topped up with a low income. Obviously, this helps to circumvent the so-called poverty trap in which some recipients of conditional benefits find themselves.

\section{Arguments for paying the $\mathrm{BI}$ without an obligation to work}

In contrast to conditional minimum-income schemes, the BI is paid without an obligation to work (i.e., it "has no strings attached"). This aspect of the BI has the following four advantages (see also the argumentation by Van Parijs \& Vanderborght, 2017). First, the considerable administrative efforts and costs required for checking whether recipients of conditional benefits are available for and willing to work would be superfluous if a BI were in place. Second, the assessment of whether a person is in fact sufficiently available for and willing to work involves arbitrariness. This is because current labor markets are characterized by considerable levels of unemployment and an often-low demand for many types of work. An obligation-free BI would abolish this arbitrariness because the assessment would no longer be necessary. Third, the absence of an obligation to work would allow people to only say "yes" to jobs in which they can see at least some value. This is tantamount to no longer being trapped in low-quality jobs (e.g., unwanted, monotonous, overly straining, or even dangerous jobs; see the "employment trap," Van Parijs \& Vanderborght, 2017, p. 21). Fourth, as people could more easily say "no" to low-quality jobs due to the BI (see Standing, 2017; Wright, 2006), it can be expected that the working conditions of existing and newly emerging jobs would improve and that the "average quality of the jobs performed by the most vulnerable can safely be expected to increase" (Van Parijs \& Vanderborght, 2017, p. 23). In fact, the BI was compared with a "permanent strike fund" (Stern, 2016, cited after Lowrey, 2018, p. 53), which would give employees much greater power.

\section{Costs of introducing $\mathrm{a} \mathrm{BI}$ and suggestions for financing it}

Ortiz et al. (2018) provide an exemplary cost estimation for a BI set at the national poverty line for different regions of the world that are in different economic situations (i.e., the absolute sum of money paid as BI in this estimation depends on the national poverty line). For most regions (i.e., East Asia and the Pacific, Europe and Central Asia, South Asia), the costs would range from $20 \%$ to $30 \%$ of the GDP. The costs would be slightly lower for the Middle East and North Africa, and they would be slightly higher for North America, Latin America, and the Caribbean. They would, however, amount to up to $62 \%$ of the GDP for Sub-Saharan Africa. Another way to look at the estimated costs is a split depending on national income levels: The costs for high-income countries would range from $27.4 \%$ to $29.9 \%$ of the GDP (depending on whether children receive a BI at $100 \%$ or $50 \%$ of the national poverty line). The costs for upper-middle-income countries would 
range from $19.8 \%$ to $22.8 \%$, for lower-middle-income countries from $23.1 \%$ to $28.0 \%$, and for lowincome countries from $62.3 \%$ to $79.1 \%$ of the GDP.

There seems to be a broad agreement that a BI cannot be financed by only drawing from extant tax sources (e.g., the personal income tax; Ortiz et al., 2018; Tanner, 2015; Van Parijs \& Vanderborght, 2017). Thus, new ways to finance a BI have to be identified and explored. Here we list the possibilities suggested by Ortiz et al. (2018). They "are supported by policy statements of the international financial institutions and the United Nations" (Ortiz et al., 2018, p. 18), but none of them is an "easy fix," and each suggestion comes with its own difficulties: ${ }^{10}$ (a) reallocating public expenditures (e.g., from military expenditures to social protection or from conditional [targeted] social assistance programs to the unconditional BI, which would need less administrative resources); (b) increasing tax revenues (altering or introducing different types of taxes like, for instance, taxes on financial transactions, property, inheritance, consumption, or natural resources; increasing the efficiency of tax collection methods; increasing tax compliance); (c) eliminating illicit financial flows (fighting for instance money laundering, bribery, or tax evasion); and (d) using fiscal and central bank foreign exchange reserves (i.e., deducting money "from fiscal savings or other state revenues stored in special funds," Ortiz et al., 2018, p. 19). Poor countries may additionally try to (e) lobby for aid and transfers with donor governments and/or international organizations and $(\mathrm{f})$ restructure existing debt by negotiating with donor countries.

Concerning the alteration of extant tax types and the introduction of new tax types, two possibilities appear to be favored: the Value Added Tax (VAT) and a tax on the ownership and consumption of natural resources. ${ }^{11}$ There are particular VAT features that make it relevant in the BI discussion: First, other than increasing the personal income tax, increasing the VAT would not make labor more expensive and/or reduce the net income of those who finance the BI (i.e., net contributors to the $\mathrm{BI}$ ). Obviously, both effects are problematic for the sustainability of a BI. Second, by applying different VAT rates to basic and luxury goods, efforts could be made to design the VAT in a socially fair way (i.e., thereby avoiding a too regressive tax profile across income classes, which has concerned economists for a long time, see Metcalf, 1995). Third, many countries share a common understanding of what a VAT is, and many countries, thus, have introduced a VAT for some time. This is especially true for the European Union (EU), where all member states have a VAT, and this common VAT basis could be a financial basis for funding an EUwide BI (Van Parijs \& Vanderborght, 2017). Some BI supporters have even argued that a steep increase in VAT could fully fund a BI (e.g., Werner, 2018), but a mix of measures is probably desirable. Moreover, introducing a VAT in countries like the US would probably be difficult even for other purposes than the BI (e.g., Metcalf, 1995).

Taxes on the ownership and consumption of natural resources (e.g., a carbon tax) are also very appealing to BI supporters and have the potential for less social inequality as compared with the VAT, because these tax types fit very well with the legitimization of a BI (i.e., the common ownership of the earth by mankind; see, for instance, Paine, 1796; Spence, 1797). Additionally, taxing the consumption of natural resources is also associated with the acknowledgement that even continued economic growth will probably not eradicate unemployment and poverty and will also contribute to undesirable climate problems. Although the term natural resources comprises a number of things (e.g., the surface of the earth, the broadcasting spectrum, the atmosphere of the earth, nonrenewable and renewable resources of the earth), various forecasts show that such

\footnotetext{
${ }^{10} \mathrm{~A}$ discussion of the problems that are associated with each of the suggestions by Ortiz et al. (2018) is, however, beyond the scope of our manuscript.

${ }^{11}$ Although a (stronger) taxation of financial capital would also be welcomed by many BI supporters, national solutions including (higher) taxation of financial transactions, inheritance, and personal wealth would possibly not be very effective considering the transnational mobility of financial capital. International solutions would accordingly be more promising but are arguably rather difficult to realize.
} 
taxes would probably only partly fund a BI (e.g., Boyce \& Riddle, 2010; Flomenhoft, 2012; Piketty, 2014).

\section{Main criticisms related to the $\mathrm{BI}$}

The BI has been criticized on many counts, with most criticism focusing on its perceived economic unfeasibility. Moreover, many critics doubt its social and political feasibility. For instance, given the absence of data from longer term implementations of a BI, and given its economic complexity, it is not clear whether the BI could in fact unfold its assumed positive effects on poverty and inequality. It also is currently not clear whether and how a BI would influence economic growth (e.g., International Monetary Fund, 2017; United Nations Conference on Trade and Development, 2017) and how sustainable a BI would be, given that econometric models predict an overall decrease in labor supply when a BI is implemented (e.g., Jongen et al., 2014). These models can, however, be criticized for being rather static by only focusing on how the supply side of work is affected (i.e., how many people in a job market would reduce their paid working hours; see Van Parijs \& Vanderborght, 2017). By contrast, these models do not take into account how the introduction of a BI would affect the demand side of work or, in other words, how jobs would (have to) change when a BI is introduced and current job incumbents could more easily say "yes" to some precarious, insecure jobs (e.g., self-employment) and "no" to others (e.g., dirty or bullshit jobs). Thus, econometric models suggest some caution concerning implementation of the BI but appear to have limited value for predicting important economic consequences of the BI. However, there seems to be a consensus that, at least in open economies, the BI would probably not systematically increase inflation but rather stimulate local economies (e.g., International Labour Organization, 2017; Van Parijs \& Vanderborght, 2017).

Furthermore, nearly all of the BI's constituent elements have been criticized. For instance, having the BI in place, which would guarantee monthly payments to all, is sometimes perceived as a severe threat to the established welfare states and even a capitulation to neoliberalism (Zamora, 2017). It has also been criticized that paying the BI individually and, thus, also to women in a household may maintain gender inequality and cement the traditional division of labor (e.g., Orloff, 2013; Robeyns, 2001). ${ }^{12}$ Moreover, concerning the absence of means testing, it has been criticized that it is unrealistic from a financial perspective to provide everyone, poor or rich, with a BI (e.g., Organisation for Economic Co-operation and Development, 2017; Tanner, 2015). One of the main and also one of the most emotionally laden criticisms focuses on the absent obligation to work when receiving a BI (e.g., Bergmann, 2004; Rawls, 1988). For many of its opponents, delinking income from labor market participation, and thereby purportedly disincentivizing work, appears to pose a major problem in terms of justice and fairness. Specifically, opponents may be concerned that a BI, particularly one that is well above the poverty line, could demotivate many people to work in demanding yet societally highly important jobs (e.g., health and elder care). This could be perceived as unfair by those who decide to work in these necessary jobs and "maintain the system," possibly even with increased demands due to lower labor supply.

Finally, some more problems have been identified that could emerge with the introduction of a BI. Among these problems are immigration pressures into countries with a BI (e.g., Pigou, 1920; Spafford, 2013) and emigration pressures out of countries with a BI by net contributors to the BI (see Van Parijs \& Vanderborght, 2017, for a related discussion). Although freedom for all is an often invoked normative standard in the BI debate, it is obvious that nations with a BI would have to protect themselves against selective immigration for economic reasons. This could be achieved by limiting illegal immigration (note, however, that this would not mean to deny the right to asylum), installing waiting periods before immigrants can receive the BI, tying the BI to citizenship,

\footnotetext{
${ }^{12} \mathrm{We}$ will further elaborate on the underlying problematic separation of work and income when portraying the psychological perspective on the $\mathrm{BI}$ in the following sections.
} 
or, although perhaps being a very utopian idea, realizing a BI for large parts of the world (e.g., Europe) or even worldwide. Obviously, a worldwide implementation of the BI would fit mostly with the general ideas underlying the BI (the world as a common good) and freedom for all as a normative standard.

\section{Psychological issues regarding the $\mathrm{BI}$}

We now connect our review of central features of the BI with psychological theories and empirical findings to provide first answers to a number of common questions regarding the BI.

Will people continue to work if they receive a BI? Or will they rather become privateers, "leisurites" (i.e., a life role that involves spending time on leisure activities; Super, 1953), or (early) "retirees"? If many or most people in a given country or geographical area in which a BI exists decided to completely forego paid employment and to live off the BI only, this would have severe consequences for organizations (e.g., lack of suitable personnel, productivity losses), other individuals such as customers (e.g., inability to meet everyday needs for food, shelter, etc.), and society as a whole (e.g., loss of security, instable economy). However, a number of psychological and managerial theories, and research evidence accumulated over the past decades, suggest that the introduction of a BI would not stop most people from working for pay, either in the same or another job or occupation, because for many people work entails much more than a means to earn a living. For instance, the classic works by Walker and Guest (1952), Herzberg et al. (1959), and Hackman and Oldham (1976) have thoroughly debunked the "homo economicus," which portrays humans as consistently rational, self-interested, and utility maximizing. In the following, we focus on research on the "lottery question," on the Negative Income Tax in North America, and on unemployment and the "latent functions" of working, as these research streams most directly address our question regarding the role of pay and income in people's life.

Research on the lottery question has asked study participants, "If by some chance you inherited enough money to live comfortably without working, do you think that you would work anyway or not?" (note that "winning the lottery" was added only in later studies to "inheriting money"; Morse \& Weiss, 1955, p. 191). The psychological construct underlying this question has been termed "nonfinancial employment commitment"-that is, the commitment to employment that is not due to income (Warr, 1982). Using a sample of 401 male workers, a classic study by Morse and Weiss (1955) found that $80 \%$ would continue working even if they inherited money. Of these workers, two thirds provided positive reasons for wanting to continue working, such as "to keep occupied," "keeps individually healthy, good for person," and "enjoy the kind of work" (p. 192). In contrast, one third of workers who wanted to keep working mentioned negative consequences of not working including "feel lost, go crazy" or "not know what to do with my time, can't be idle" (p. 192).

A review of research on the lottery question over several decades showed that subsequent studies were able to replicate Morse and Weiss's (1955) original findings. Specifically, 22 studies conducted between 1969 and 2005 demonstrated that, across studies, more than two thirds of people would continue working as compared with one third who would stop working (i.e., "continue working" mean $=76 \%$, "stop working" mean $=24 \%$; Paulsen, 2008). However, Paulsen (2008) argued that, to better understand the implications of research on the lottery question, it is important to take a closer look at the specific response options provided to respondents in the primary studies and follow-up questions to the question asked. For example, in their original study, Morse and Weiss (1955) also asked workers, "Would you still keep on doing the same type of work you are doing now?" and found clear occupational differences. Whereas most farmers (69\%) and people in professional jobs (68\%) responded affirmatively to this question, a much lower percentage of people in blue-collar jobs (34\%) indicated that they would continue working in their jobs. Paulsen (2008) identified 12 studies that distinguished people's responses to the lottery question 
into three categories, "continue at current job" (mean =38\%), "continue working elsewhere" or "continue working under different conditions" ( $m e a n=38 \%)$, and "stop working" (mean = 21\%). Moreover, comparable shares of people indicating to continue working and to stop working were found across very different countries and cultures (de Voogt \& Lang, 2017). Thus, overall, these findings suggest that most people would want to remain employed even if they could afford to stop working immediately while still meeting their basic needs. Importantly, however, half of them would want to work in a different job or under different working conditions (for recent temporal trends and a discussion of the limitations of the lottery questions as a measure of work ethic, see Highhouse et al., 2010).

Research on the lottery question can be criticized for presenting people with a hypothetical and, at the same time, highly unlikely scenario that only very few people may ever encounter in their lives. Thus, it may be questioned whether people's responses to the question would predict their behavior if they actually won the lottery or inherited a lot of money (or received an unconditional $\mathrm{BI}$ ). Interestingly, some research with actual lottery winners suggests that most people who could live comfortably without working for pay would still choose to work (Arvey et al., 2004; Falk \& Mäendpää, 1999). For example, Arvey et al. (2004) surveyed 117 lottery winners and found that 100 of them (85.5\%) continued to work after winning (i.e., "engaged in regular jobs for which wages were being paid, regular hours maintained, and so forth"; p. 412), whereas only 17 individuals decided to stop working completely (14.5\%). The amount of money won in the lottery was positively associated with quitting work, whereas job satisfaction and work centrality were negatively correlated with quitting. Furthermore, the negative association of work centrality with quitting was stronger among those who won a large amount of money (i.e., more than 3 million dollars). Importantly, the results of the study have to be interpreted with caution, as the response rate among lottery winners contacted was only $9 \%$. However, largely comparable results were found in a Swedish study that could link lottery winners with their related administrative data (i.e., the study focused on hours worked, so no self-selection bias existed; Cesarini et al., 2017). Another study with lottery winners found that unfavorable working conditions were associated with lottery winners' decisions to quit, take leaves from work, and reduce their work hours (Hedenus, 2012). In particular, high levels of physical job strain, lack of training possibilities, low satisfaction with coworkers, and lack of working-time autonomy were related to lottery winners' decision to spend less time at work. Thus, overall, this line of research suggests that most people would continue to work for pay if a BI was introduced. Among those who would continue to work, however, about half would stay in the same job, whereas the other half would change jobs or reduce their working hours. Moreover, people's decisions regarding their employment upon the introduction of a BI will likely depend on the existing working conditions (including demands and resources) in their occupation, organization, and job. For instance, research on the lottery question suggests that white-collar and professional workers will be more likely to continue working than will blue-collar workers when receiving a BI.

Studies in affluent countries on the effect of cash transfers on the recipients' actual work behavior come to very similar conclusions (see Forget, 2018; Marinescu, 2018). Although none of these studies investigated the effect of a BI and most of these studies had a fixed duration, they provide some interesting insights. In a summary of the four large-scale experiments on the effect of a negative income tax (Friedman, 1962) in the US and one similar large-scale study in Canada, Forget (2018) concluded that the decrease in hours worked was, depending on the site of the experiments, either not statistically significant or small (see also Robins, 1985). Although the primary earners of a family (husbands) hardly reduced their work hours, the secondary earners (wives) reduced their work hours between 3\% (in the Canadian study) and 28\% (in Seattle/Denver), presumably to take care of family members. The effect of other cash transfers (e.g., from the Eastern Band of Cherokee Indians Casino Dividend or Alaska Permanent Fund) on working hours was also either null or small, respectively (Marinescu, 2018). 
Additional evidence for the conclusion that most people would continue to work-either in the same job, organization, or occupation; in a different job, organization, or occupation; or under different working conditions_-comes from research on unemployment and the "latent functions" of working (i.e., nonfinancial benefits of working as opposed to "manifest functions" or financial benefits of working; Jahoda, 1983). These functions are considered "latent" because people are not necessarily aware of their positive effects (see also Herzberg et al., 1959, for the related motivationhygiene theory). According to Jahoda (1983), the latent functions fulfill important psychological needs and include time structure, social contacts, collective purpose (or common goals), status, identity, and activity provided by employment. Jahoda (1981) argued that in modern societies, paid work is the most important domain that allows people to experience these latent functions with sufficient intensity and regularity. The lack or loss of these latent functions (called "deprivation" by Jahoda, 1981), in addition to a loss of income, is assumed to cause psychological strain (see also Warr, 1987). Accordingly, a meta-analysis on the effects of unemployment on mental health showed that unemployed people experience higher depression, anxiety, and psychosomatic symptoms as well as lower subjective well-being and self-esteem compared with employed people (Paul \& Moser, 2009). The meta-analysis also showed that men and blue-collar workers experienced more distress due to unemployment than women and white-collar workers. Related research shows that unemployed people are motivated to seek employment not only for financial but also for personal and social reasons (Mor-Barak, 1995). The well-being of those who regain employment increases significantly. Even people in precarious jobs (e.g., low wage, temporary contract, lack of fit between worker and job requirements) are more satisfied with life than those who remain unemployed (Grün et al., 2010). Finally, experiencing unemployment may even lead to a more persistent decrease in life satisfaction than other critical life events (e.g., divorce or widowhood; Clark \& Georgellis, 2013; Lucas et al., 2004).

Furthermore, the availability of the latent functions of working meets important individual needs and has been found to be associated with improved health and well-being (Jahoda, 1981). Indeed, primary research conducted with a representative sample of the German population shows that both full-time and part-time employees, including unskilled manual workers, consistently self-reported having higher levels of time structure, social contact, collective purpose, and regular activity than unemployed persons and other people who are not part of the labor force (i.e., students, homemakers, retirees; Paul \& Batinic, 2010). Moreover, full-time employees reported higher levels of status and identity as well as psychological well-being than unemployed persons. All five latent functions as well as people's financial situation correlated positively with psychological well-being; moreover, in a regression analysis, the financial situation, status, and social contacts emerged as most important predictors. With respect to demographic characteristics, Paul and Batinic (2010) showed that young men from higher social classes, who had a partner and children, reported the highest levels in the latent functions of working. A longitudinal study with four measurement waves over 1.5 years further showed that self-reports of the latent functions positively predicted change in employee health, whereas health did not have reverse effects on the latent functions (Selenko et al., 2011). Overall, this research suggests that, in addition to income and other extrinsic sources of motivation, intrinsic factors such as the latent functions of working play an important role for people's work motivation and well-being.

Jahoda's $(1981,1983)$ work could be criticized for seeing employees as passive recipients, who only react to the availability or lack of the latent functions of working (Paul \& Batinic, 2010). In contrast, psychological action theories conceive individuals as active, self-determined agents, who tend to initiate changes in their environment and personal development to better use their abilities and meet their needs (Frese \& Zapf, 1994; Heckhausen \& Heckhausen, 2008). In the IWO psychology context, action regulation theory suggests that employees actively redefine tasks assigned to them by others and set their own work-related goals, mentally regulate their goal-oriented behavior at work (e.g., planning, feedback processing), and show personal initiative (Frese \& Fay, 2001; Hacker, 2003). More broadly, the theory assumes that most if not all individuals, across 
the entire adult lifespan, strive to engage in work-related activities and to continually improve themselves and that people's occupation and paid employment provide the most important contexts to meet those needs (Zacher et al., 2016). Similarly, self-determination theory proposes that people strive to be as autonomous as possible in their actions, to belong to social groups, and to demonstrate their personal competence (Deci \& Ryan, 1985); for many, work (both paid and unpaid) is a primary activity to fulfill these needs (Gagné \& Deci, 2005). Evidence for this assumption comes, for instance, from research on retirement and bridge employment, which suggests that many retirees remain active and "busy" (Beehr \& Bennett, 2015; Ekerdt, 1986; Griffin \& Hesketh, 2008).

Would today's workplaces have to change if people's basic financial needs were met through a BI? Based on action regulation and self-determination theories, we argue that workplaces would have to change to become more "humane"- that is, to better meet individuals" needs and challenge their abilities in positive, growth-oriented ways. Action regulation theory outlines the following conditions that have to be met for work to have positive consequences on people's wellbeing, motivation, and performance: work has to be feasible ("Ausführbarkeit”), not cause physical damage or psychological strain, and, through complete tasks, should support individuals' learning and development (Hacker, 1986). Similar to the notion of task identity (Hackman \& Oldham, 1976), complete tasks entail that employees are involved in all stages of the action regulation process (e.g., goal setting, planning, execution, feedback processing) and at all levels of the psychological action regulation hierarchy (e.g., physiological demands, intellectual demands). Overall, action regulation theory suggests that if a BI was introduced, people would not become inactive but would still be motivated to engage in work activities that are "complete" - that is, designed to better meet their needs for activity and development. As a caveat, it is important to note here that our expectations regarding positive workplace effects of the BI may be Western-centric and that cultural characteristics can moderate the effects of work design on individual outcomes, such as job attitudes and behavior (Erez, 2010). For instance, research has shown that motivational job characteristics, such as autonomy and task identity, are not necessarily positively related to job satisfaction in less "Westernized" cultures (for a review, see Judge et al., 2001).

How would the introduction of a BI affect workers in currently precarious, "indecent," and "dirty" jobs and occupations? Research suggests that the "working poor" members of the workforce attempt to make a living in a strong situation characterized by low-wage work, insecurity, and poverty (Leana et al., 2012). Leana et al. (2012) argue that the working poor are severely disadvantaged in terms of job attachment, career attainment, and job performance (for recent critiques of neoliberalism in the IWO psychology literature, see Bal \& Dóci, 2018; Mumby, 2019). Similarly, "indecent work" entails working conditions that are not physically and interpersonally safe, a lack of access to health care, inadequate compensation, insufficient free time and rest, and organizational values that are inconsistent with family and social values (Duffy et al., 2017; International Labour Organization, 1999). Research suggests that indecent work is associated with lower physical and mental health because workers are not able to meet their needs for survival, social contribution, and self-determination (Duffy et al., 2019). Moreover, long and inflexible work hours lead to the experience of work-family conflict among caregivers of young children or frail relatives (Hammer et al., 2002) and, due to a lack of recovery, have a negative influence on health (Van der Hülst, 2003). "Dirty work" involves stigmatized tasks and occupations that threaten workers' professional self-esteem and social identity (Ashforth \& Kreiner, 1999). Examples of dirty jobs include low-prestige jobs such as cleaners, butchers, and undertakers, but also jobs with a high prestige such as dentists.

The introduction of a BI would allow workers to leave precarious, indecent, and dirty jobs and occupations while still being able to meet their basic needs. Thus, especially when unemployment and underemployment rates are low, organizations and society would have to find ways to improve working conditions, including pay, benefits such as health care, occupational safety, and work hours, as well as the social prestige of formerly "dirty" jobs and occupations to make 
them attractive to those who want to earn an income that is additional to the BI (e.g., to finance their life expenses like real-estate loans, hobbies, vacations). As we have argued above, we expect there will be enough people who will want to work and earn an additional income, but, in contrast to many contemporary jobs, working conditions and prestige of these jobs would have to better meet their personal needs, including needs for occupational safety and self-esteem. Of course, the margins of such investments are likely to be high for different stakeholders. Thus, organizations and society have to deliberate whether certain jobs and occupations are necessary for their functioning and, if the answer is "yes" and current unemployment and underemployment are low, enhance not only the pay but also the working conditions and prestige of these jobs. Of course, such changes imply societal costs, which may partly neutralize the positive effects of the BI. However, it may also be possible to shift financial resources from unnecessary "bullshit jobs" (Graeber, 2018) to necessary jobs. If changing the working conditions and prestige of certain jobs and occupations is not possible due to a lack of resources, organizations and society will have to either automatize them (i.e., assign tasks to robots) or accept that certain jobs and occupations will disappear. In some cases, the disappearance of certain jobs might even have positive consequences. For instance, if the meat-producing industry is forced to shut down plants because fewer people are willing to work there, meat consumption will go down with positive effects on individual health, societal spending on health care, and carbon dioxide emissions. More generally, the introduction of a BI could lead to more health-, social-, and environment-conscious consumption; an increased focus on the quality of products and services (as opposed to quantity); and greater attention to worker health and well-being (as opposed to productivity and efficiency; see Bal \& Dóci, 2018).

After the potential introduction of a BI, if employees cannot meet their personal and professional needs in their current job, they might more often consider becoming self-employed, as selfemployment often allows people to better align their work activities with their personal needs for autonomy, belongingness, and competence (Douglas \& Shepherd, 2002; Feldman \& Bolino, 2000). The BI could be perceived as enabling people to participate in the labor market in the ways they prefer (including various forms of self-employment) and, thus, to become more self-determined (Sen, 2001). Importantly, however, it has to be considered that the decision to become selfemployed would require initial backing investments. At the same time, we expect that the introduction of a BI would lead to more job, organizational, and even occupational mobility of individuals who are not satisfied with their working conditions or occupational prestige (Feldman \& $\mathrm{Ng}$, 2007; Ng et al., 2007). Although such mobility may have a number of positive consequences for individuals, organizations, and society (e.g., increased satisfaction, innovation; Fouad \& Bynner, 2008; Kalleberg, 2008; Kalleberg \& Mastekaasa, 2001), it also incurs costs for the recruitment, selection, and onboarding of newcomers, and these costs will have to be compensated by the positive consequences.

What would people do who decide to quit their jobs, leave the labor market entirely, and live off the BI? As we have argued before based on psychological theories (Deci \& Ryan, 1985; Hacker, 1998; Jahoda, 1983), people are intrinsically motivated to be active and to perceive themselves as socially connected and competent. However, although paid employment is certainly a major way to meet these needs, it is not the only one. Other potential, already quite common ways to feel autonomous, socially integrated, and competent are family work or caregiving, volunteering, and personal projects during leisure time. Overall, we expect that the introduction of the BI would not turn people into passive "leisurites" but that they will strive to meet their personal, intrinsic needs in other meaningful ways including time and energy spent for caregiving, volunteering, and personal projects - even if these activities offer few direct and extrinsic rewards.

Family work includes providing care for and raising young or disabled children as well as unpaid care for older and frail relatives living at home (often one's parents or parents-in-law). This type of work is currently perceived by many employees, most of whom are women, as an activity that is difficult to combine with paid employment (Duxbury \& Done, 2015; Smith, 
2004). Even though informal caregiving work is socially and societally relevant, and often perceived as deeply meaningful by caregivers themselves, it is typically linked to much lower financial rewards and social recognition than comparatively less important and meaningful work that is part of traditional paid employment. Employees with informal caregiving responsibilities sleep less and report poorer sleep quality, feel less healthy and more exhausted, and have higher turnover intentions (as their paid work hinders their ability to meet their family responsibilities) than employees not providing informal care (DePasquale et al., 2019; Greaves et al., 2015, 2017; Pinquart \& Sörensen, 2003). The introduction of a BI would give caregivers more financial security, flexibility, and choices, as they could change jobs, reduce their work hours, or quit paid work entirely. Moreover, the introduction of a BI could also, at least to some extent, help to better recognize this form of unpaid, currently often underappreciated, and yet societally extremely important type of work. These changes, in turn, might help to alleviate the physical and psychological burden experienced by many people with informal caregiving responsibilities.

Another form of unpaid work that supports societal functioning and well-being is volunteering. Many older employees and retirees engage in volunteering activities, such as helping out in food pantries, retirement homes, refugee homes, animal shelters, national parks, and libraries and museums. Interestingly, research with older European volunteers suggests that lower human and social capital (e.g., lower education, lower health status, and being widowed, divorced, or single) is associated with a greater likelihood of volunteering, with the goal of enhancing self-esteem and social connections and dealing with personal problems (Principi et al., 2016). The introduction of a BI would provide greater financial security for those who help others and, indirectly, society and thus constitute another form of recognition for their contributions (see also Smith, 1776/2010). The BI further raises interesting research questions regarding the demographic composition of workforces and populations. For instance, will people decide to have more children due to greater financial stability and a better work-life balance? Does the BI contribute to increased longevity due to better working conditions (see Gonzalez-Mulé \& Cockburn, 2017)?

A BI could also support individuals who want to recover from highly demanding paid employment by working on personal projects, such as engaging in art and craft activities, sport activities, or learning activities (e.g., in a community college). Research suggests that particularly those who worked in physically straining and psychologically demanding jobs and occupations benefit psychologically from entering retirement (Pinquart \& Schindler, 2007; Wang, 2007). Consistent with research on recovery (Sonnentag et al., 2017), retiring and engaging in activities that differ from paid employment with respect to their physical, mental, and socioemotional demands benefit people's health and well-being. The BI might also offer greater flexibility in switching between paid and unpaid work, as well as more and less burdensome activities, across the working lifespan. For instance, the BI could help avoid the often lamented "rush hour of life," in which career and family demands often collide, particularly for women (Bowman et al., 2013).

Overall, we expect that the introduction of a BI would lead to a greater recognition of and, consequently, more engagement in societally important pursuits such as childcare, eldercare, and volunteering. By relieving employees from fundamental concerns about their own and their family's survival and by allowing them to choose and engage in work activities that better meet their abilities and needs, the BI should lead to improved health and well-being (including a greater sense of meaning at work; see Forget, 2011). Beyond those positive individual consequences, we also expect that the introduction of a BI would lead to greater organizational investments toward the improvement of working conditions and more societal investments in education as well as strategies to support caregivers and community volunteers. Of course, there are a number of interesting and important questions that remain to be answered: How would the BI affect the gender distribution for these activities (e.g., women more likely to opt for caregiving, men for their hobbies)? What about possible seasonal effects, such that people decide to work in the winter months and take leisure time during the more clement weather? 
How would the BI influence workers' perceptions of fairness? Our second introductory quote suggests that the BI, even though it would be paid to all (adult) members of a society, might raise some questions about fairness and justice: "it is unfair for able-bodied people to live off the labor of others" (Elster, 1986, p. 719). The IWO psychology literature has typically distinguished between distributive, procedural, interpersonal, and informational justice. Research has shown that these fairness perceptions are meaningfully associated with employee attitudes and behavior (Colquitt et al., 2001). We argue that, regarding distributive justice, the BI should be perceived as fair because it is paid universally, and those who are able and willing to additionally work for pay will have more money available than those who do not. In terms of procedural, interpersonal, and informational justice, it will be important to explain clearly, for example, why the BI is introduced and who has a right to receive it (e.g., based on fiscal residence). However, we agree with Elster (1986) that, at present, the BI is likely to clash with many people's perceptions of deontic justicethat is, their assumptions about the moral responsibility of "able-bodied people" to work for pay (even if the work is potentially harmful; Cropanzano et al., 2003). The BI should particularly violate the values and beliefs of those with a strong Protestant work ethic (Furnham, 1984; Weber, 1905). Currently, the Protestant work ethic is associated more strongly with paid employment than with work in a broader sense. Consistent with the arguments presented in the previous sections, we believe that the introduction of the BI, over time, would lead to a broader (and fairer) understanding of what constitutes important and meaningful work in a society, including family, caregiving, and household work. It is likely that many people, based on the notion of deontic justice, will always believe that it is important to make use of one's abilities and potential through work. However, paid employment would only be one form of relevant work in a society with the BI.

\section{Potential negative psychological consequences}

The BI-and in fact all other measures addressing poverty and inequality-is not a silver bullet that can solve all extant problems and does not produce new problems. In fact, implementing a BI would most likely create some new societal, economic, and individual problems (see also the above section on criticisms related to the $\mathrm{BI}$ ). The psychological perspective on the BI that we want to advance suggests further negative consequences that the implementation of a BI might have and that - to the best of our knowledge- have not yet been thoroughly discussed in the BI debate.

First, it depends strongly on the concrete design of a BI whether it will be a promising and innovative social welfare instrument or only "a sop to the poor." A BI only at or even under the poverty line would not really give BI recipients more choices and enable them "to be free" (Zwolinski, 2013), whereas a BI clearly above the poverty line would substantially improve their lot and allow them to take part in the political, social, and cultural lives of their countries (Werner, 2018). In accordance with International Labour Organization standards (see Ortiz et al., 2018), we also believe that introducing a BI must not lead to an overall reduction in social welfare (i.e., the BI would not replace all public transfers as suggested, for instance, by Murray, 2008, and Sennett, 2003). The eligibility criterion for receiving a BI is also of central importance: For instance, if fiscal residence is the criterion (see Van Parijs \& Vanderborght, 2017) and if many people live in a country without having fiscal residence, these people would be the most vulnerable part of the population and, thus, expected to end up in the most unfavorable jobs. Thus, although BI recipients would have more choices, people without fiscal residence would probably have even fewer choices than before the introduction of the BI. Thus, for the BI to unfold its positive effects to the maximum degree (i.e., addressing structural inequalities in society, removing low-quality jobs, and improving workplaces), the eligibility criterion should minimize the number of people who are not entitled to the BI in a society. 
Second, because receiving a BI would strengthen the power position of each recipient vis-à-vis their employer (e.g., Stern, 2016; Van Parijs \& Vanderborght, 2017), it becomes easier to say "no" to tasks, jobs, and also to organizations that offer work that is not or no longer appealing to (potential) employees. Thus, BI recipients' task- or job-specific motivation as well as organizational commitment could change, oftentimes in a negative direction. This might particularly hold for jobs and organizations where no noticeable efforts are made to improve the working conditions, whereas in comparable jobs and organizations related efforts are made (i.e., low equity; Adams, 1965). If the BI is introduced, employers therefore might have to make work (more) fair, dignified, stable, and secure (see also the discussion on "decent work"; Blustein et al., 2016); increase autonomy, task variety, and task significance (Hackman \& Oldham, 1976); and reduce work-related stressors to make tasks and jobs more attractive to (potential) employees.

Third, established organizations may become less innovative, whereas self-employed people and new organizations may bring about an even higher share of all innovations than is currently the case. This is because the BI offers a financial buffer and, thus, potentially enables creativity, innovation, and entrepreneurship among those with fewer economic resources. Moreover, innovation and the presence of at least some stressors are positively related, at least under some circumstances (e.g., Sacramento et al., 2013). For example, challenge stressors like workload, time pressure, job scope, or high responsibility (LePine et al., 2005) may be associated with increased innovativeness because people can see a positive relationship between their efforts and the chance to successfully overcome these demands. In this process, innovative ideas may be generated. However, if BI recipients are unwilling to remain in jobs and organizations in which such challenge stressors prevail, creative ideas as an adaptive response to these stressors may also fail to manifest. They may instead manifest relatively more often in situations in which people accept the presence of such stressors (i.e., self-employment and work for new companies).

Fourth, organizations would probably have more difficulties with planning and organizing their everyday business if a BI was implemented because typical consequences of a BI comprise a higher fluctuation and more part-time work among employees. Thus, it may become more difficult to ensure sufficient staffing even in high-reliability sectors (e.g., police or firefighter staff, medical teams). Parallel problems related to the increased difficulties in work organization may negatively affect very popular approaches like "just in time" production (e.g., Miltenburg, 1989). Further, organizations might have to spend significantly more financial and human resources for recruitment, selection, and retention activities to meet their business needs. However, organizations may also benefit from reduced working hours because employees with a BI and reduced working hours may be more resilient and healthier (for the relation of long working hours and health, see Bannai \& Tamakoshi, 2014; Brauner et al., 2018).

Fifth, entire branches of the current economy may disappear if they do not invest sufficient effort toward improving their working conditions and if it is not possible to fully automatize their work processes. This may especially affect branches like the meat-producing industry or parts of the energy sector (e.g., coal mining), where more sustainable alternatives are currently already realized, explored, or at least on the horizon. Although there is agreement that a BI would not generally increase inflation (see above) in open economies, prices for goods and services coming from the affected branches may nevertheless increase. Such increased prices may then, to a small degree, offset positive economic effects of a BI.

Finally, people's attitudinal and behavioral reactions to the introduction of a BI likely depend on the fit between this economic and social policy and the dominant cultural values (or zeitgeist) of a given country or region (see Hofstede, 1980). For instance, in the US (and other highly individualistic cultures) a BI might be met with greater skepticism or resistance given the American creed of independence, self-reliance, primacy of "merit" for getting ahead, and antipathy to centralized government. In contrast, a BI might be received more favorably in social-democratic, socialist, and postsocialist countries in Asia and Europe, in which people are more likely to endorse the belief that the government is responsible for all citizens' welfare and must provide 
for them financially (see Frese et al., 1996). It may be possible, of course, that the COVID-19 pandemic and its vast economic and social consequences will lead to changes in individual and societal attitudes toward the BI over the coming months and years, especially in neoliberal and individualistic countries (Rudolph et al., 2020; Sibley et al., 2020).

\section{Discussion}

Our overarching goals with this article are to introduce the idea of the BI to scientists and practitioners in the field of IWO psychology; to review its history, its most important features, possible positive and negative consequences, related measures, and associated advantages and criticisms; and to provide some first psychological answers to common questions regarding the BI. As we believe that IWO psychology has much to contribute to the debate on the BI, we hope to initiate an informed and differentiated discussion on the BI in our field, which has already been taking place in several related fields, including economics and sociology, for some time. In this final section, we outline a number of suggestions for theory development in IWO psychology, future empirical research, and potential practical applications regarding the BI.

\section{Implications for theory development}

As our review has shown, a number of existing theories, including Jahoda's (1983) latent functions theory, action regulation theory, the job characteristics model, and self-determination theory, can be considered to provide preliminary answers to common questions regarding the BI. We suspect that several other theories developed in our field could be used to speculate on "what would happen" if a BI was introduced. For example, equity theory (Adams, 1965) and discrepancy theory (Lawler, 1971) are often invoked in studies on pay and employee satisfaction (e.g., Judge et al., 2010; Williams et al., 2006). At the same time, beyond the rather descriptive research on the "lottery question" (Morse \& Weiss, 1955), there has been no systematic theory development that considers individuals' reactions toward the $\mathrm{BI}$ idea as well as the psychological consequences of the introduction of a BI. Thus, we believe that it is an important task for IWO psychologists to develop theory that explains why individuals including employees, unemployed people, and those working outside of the labor market (e.g., informal caregivers, volunteers) support or reject the idea of introducing a BI. We expect that besides demographic (e.g., age, gender) and employment characteristics (e.g., pay level), psychological factors such as knowledge about the BI, work centrality, other work-related attitudes, and certain personality characteristics (e.g., promotion and prevention orientation; Higgins, 1997) could play a role in this respect. Moreover, the culture of countries or regions in which the BI is implemented would have to be considered.

Theory is also needed concerning the likely attitudinal and behavioral consequences when a BI is introduced. Based on our review of the literature, we would expect that individuals become more reflective and critical of the role of paid work in their lives and, in the case of employees, of their job, organization, and occupation. For example, people might become more likely to question the importance of paid work in their lives and the meaningfulness of their work activities (e.g., Bunderson \& Thompson, 2009). At the same time, employees might become more willing to question the status quo in their jobs and to voice their concerns (LePine \& Van Dyne, 1998) or they might more often initiate ways to improve the fit of their work tasks, relationships, and cognitions with their abilities and needs (i.e., job crafting; Wrzesniewski \& Dutton, 2001). ${ }^{13}$ Importantly, we also need more theory on the individual (e.g., personality) and contextual factors (e.g., current

\footnotetext{
${ }^{13}$ Of course, these expected positive effects of introducing a BI only hold if the absolute majority of a political community receives the BI. Otherwise, people who are not entitled to the BI may be willing to replace unsatisfied BI recipients even if BI recipients' jobs are low wage, monotonous, overly straining, or even dangerous jobs. If a large proportion of a political community is not entitled to a BI, the positive effects of the BI would probably be offset.
} 
working conditions, cultural values) that may moderate people's reactions to the BI idea. In the long run, these psychological processes related to the BI might lead to improved intrinsic motivation, higher quality of products and services provided, and greater occupational health and well-being.

The required theory development could benefit from contrasting the BI with related measures such as the living wage. Although the individual and societal economic consequences of the living wage have been intensely studied (e.g., on wages, hours worked, unemployment; for an overview, see Card \& Krueger, 2015), there is much less research on how receiving a living wage may change people's general outlook on (the relation of) work and life. For instance, it is not clear whether living-wage recipients enjoy analogous advantages that we would predict for BI recipients: For instance, do they also gain freedom to question the status quo in their jobs and voice their concerns, to take responsibility for the design of their jobs (i.e., job crafting), and also to say "no" to precarious, dirty, or indecent work? In summary, we challenge IWO psychology researchers to develop theory on the $\mathrm{BI}$-also in contrast to measures like the living wage-to refresh and advance the scientific, political, and societal debate on this measure.

\section{Implications for future empirical research}

With more specific psychological theories and models on the BI in place, it will be important to use rigorous research methods to examine individual and higher level reactions to the proposal and actual introduction of a BI as well as individual and contextual factors that moderate these effects. Obviously, investigating reactions to the general idea of introducing a BI will be relatively easier than examining the consequences of actually introducing a BI. For example, researchers could use experimental vignette methodology studies (Aguinis \& Bradley, 2014) to manipulate different features of the BI (e.g., level of payments, payment conditions, recipients) and of the context in which it is introduced (e.g., globally vs. specific geographical areas, occupations, jobs). As outcomes, researchers could examine people's and teams' level of support for the idea, as well as their hypothetical work satisfaction and motivation.

Using quasi-experimental field studies (Grant \& Wall, 2009), researchers could, possibly with the help of governmental or private funding agencies, introduce the BI on a relatively small scale (i.e., not entire countries but, for example, in selected jobs, units, or organizations). Before the intervention, as a baseline measure, and for some time after the intervention, they could measure people's experiences and behaviors (e.g., satisfaction, proactive work behavior). However, given limited resources (e.g., funding, time) and potential social and ethical problems (e.g., fairness), this approach would be much more challenging to implement. Moreover, the conclusions of a smallscale implementation could be questioned, as the "John Henry effect" (i.e., the control [non-BI] group being aware of the existence of the experimental [BI] group and reacting to that knowledge in ways that otherwise would not occur; Saretsky, 1975) constitutes a potential threat to validity. In contrast, a universal implementation of the BI would not allow an investigation of causal effects, as there would be no control group. Nevertheless, a few large-scale IWO psychology studies like this have been implemented in the past. For instance, in collaboration with the World Bank, IWO psychology researchers have conducted training on proactive work behaviors with 500 participants and surveyed these participants for 2 years (Campos et al., 2017). Overall, we suggest that we need more systematic studies in our field that address psychological research questions on the BI. Although in most cases it will not be possible to actually implement a BI and evaluate its consequences, we challenge researchers to creatively develop and test such research questions using methods available to them and perhaps also to develop new methods if they are needed to study this complex research question. 


\section{Implications for IWO psychology practitioners}

The discussion of the BI, as well as its potential introduction, has important implications for various stakeholders in applied settings including IWO psychologists who are working in human resource departments or consultancies, employees and managers, and labor union/work council representatives, as well as politicians, lawyers, and other policy makers. We expect that, given global trends such as increased automatization and digitization, rapid demographic changes, and uncertain and unstable economic developments, the public debate on introducing a BI will gain traction over the next years. Thus, the first practical implication to be considered is that all IWO psychologists should have a fundamental understanding of the BI as well as its value and problems. For instance, they could contribute to alleviating the common fear that people will stop working completely and become passive "leisurites" if a BI is introduced. Moreover, they could participate in discussions on how to improve working conditions and create attractive alternative ways to be active and engaged if a BI is introduced.

Second, we think it is useful that employees, managers, and IWO psychology practitioners working in human resource departments regularly take time for a "thought experiment" in which they consider how current work conditions and the recognition awarded to certain jobs and occupations would have to change if a BI was introduced. In other words, we challenge practitioners to think about why employees would work in certain jobs or occupations for the pay only and which factors could make these jobs or occupations more attractive and motivating. For instance, how would changing the work hours, job responsibilities, reporting relationships, or the broader culture affect employee motivation, performance, and well-being? Even if a BI was not introduced, changing jobs, organizations, and occupations in ways that motivate and support employees by improving their person-job and person-organization fit should have positive individual and organizational consequences (Kristof-Brown et al., 2005; Lievens et al., 2001).

Finally, we suggest that practitioners should carefully consider both the potential positive and negative consequences of introducing a BI. For instance, individuals might at first feel "lost" if they gave up an unattractive job and live off the BI only; a consequence might be that they need to make use of professional counseling more frequently. Further, in addition to the immense financial costs of introducing a BI (a discussion of which was beyond the scope of this article), organizations may have difficulties attracting and retaining employees for certain positions and, in the long run, may become less productive and innovative. At the broader societal level, some classes of jobs and occupations (e.g., meat production or coal mining) might disappear entirely, because the BI might lead people to question the meaningfulness and ethicality of jobs more often. At the same time, practitioners should consider how the potential positive consequences of a BI might outweigh the expected negative consequences. For instance, we have suggested that a BI might lead to greater individual health and well-being (due to the removal of existential stressors) while also increasing employees' intrinsic motivation, willingness to learn and develop, and experienced meaningfulness at work. Taken together, these positive changes at the individual level should, in the long run, also benefit organizations and society as a whole.

\section{Conclusion}

In this focal article, we described the idea of the BI and provided arguments for its specific features (i.e., paid on individual basis in cash, no means test, unconditional payment). We briefly outlined the history and feasibility of the BI as well as the most important reasons for the growing interest in the idea, mostly outside of the field of IWO psychology. In addition to the BI's potential positive and negative consequences at the individual, organizational, and societal levels, we provided preliminary answers to common questions on the BI from a psychological perspective and derived 
implications for IWO psychology research and practice. We hope that this article will now start a critical debate also in our field so that we as IWO psychologists will be better prepared to contribute to a potential future in which a BI might be introduced.

\section{References}

Ad Hoc Committee on the Triple Revolution. (1964). The Triple Revolution. The Committee.

Adams, J. S. (1965). Inequity in social exchange. In L. Berkowitz (Ed.), Advances in Experimental Social Psychology (Vol. 2, pp. 267-299). Academic Press.

Adler-Karlsson, G. (1979). The unimportance of full employers. IFDA Dossier, 2, 216-226.

Aguinis, H., \& Bradley, K. J. (2014). Best practice recommendations for designing and implementing experimental vignette methodology studies. Organizational Research Methods, 17, 351-371. doi: 10.1177/1094428114547952

Aguinis, H., \& Cascio, W. F. (2008). Narrowing the science-practice divide: A call to action. The Industrial-Organizational Psychologist, 46, 27-34.

Aldrete, G. S. (2004). Daily life in the Roman city: Rome, Pompeii and Ostia. Greenwood Publishing Group.

Ambrose. (1927). S. Ambrosii De Nabuthae: A commentary (translated by Martin McGuire). Washington, DC: Catholic University of America Press.

Arvey, R. D., Harpaz, I., \& Liao, H. (2004). Work centrality and post-award work behavior of lottery winners. Journal of Psychology, 138, 404-420. doi: 10.3200/JRLP.138.5.404-420

Ashforth, B. E., \& Kreiner, G. E. (1999). "How can you do it?" Dirty work and the challenge of constructing a positive identity. Academy of Management Review, 24, 413-434. doi: 10.5465/amr.1999.2202129

Bal, P. M., \& Dóci, E. (2018). Neoliberal ideology in work and organizational psychology. European Journal of Work and Organizational Psychology, 27, 536-548. doi: 10.1080/1359432X.2018.1449108

Bannai, A., \& Tamakoshi, A. (2014). The association between long working hours and health: A systematic review of epidemiological evidence. Scandinavian Journal of Work, Environment \& Health, 40, 5-18. doi: 10.5271/sjweh.3388

Barry, B. (1996). Real freedom and basic income. Journal of Political Philosophy, 4, 242-276. doi: 10.1111/j.1467-9760.1996. tb00052.x

Bastagli, F., Hagen-Zanker, J., Harman, L., Barca, V., Sturge, G., Schmidt, T., \& Pellerano, L. (2016). Cash transfers: What does the evidence say? A rigorous review of programme impact and the role of design and implementation features. ODI.

Beehr, T. A., \& Bennett, M. M. (2015). Working after retirement: Features of bridge employment and research directions. Work, Aging and Retirement, 1, 112-128. doi: 10.1093/workar/wau007

Bellamy, E. (1983). Looking backward, 2000-1887. Penguin. (Original work published 1888)

Bergmann, B. (2004). A Swedish-style welfare state or basic income: Which should have priority? Politics \& Society, 32, 107118. doi: $10.1177 / 0032329203261101$

Bezrukova, K., Spell, C. S., Perry, J. L., \& Jehn, K. A. (2016). A meta-analytical integration of over 40 years of research on diversity training evaluation. Psychological Bulletin, 142, 1227-1274. doi: 10.1037/bul0000067

Blustein, D. L., Olle, C., Connors-Kellgren, A., \& Diamonti, A. J. (2016). Decent work: A psychological perspective. Frontiers in Psychology, 7, 407. doi: 10.3389/fpsyg.2016.00407

Bowman, D., Bodsworth, E., \& Zinn, J. O. (2013). Gender inequalities and risk during the "rush hour" of life. Social Policy and Society, 12, 277-286. doi: 10.1017/S1474746412000553

Boyce, J. K., \& Riddle, M. (2010). CLEAR economics: State-level impacts of the carbon limits and energy for America's renewal act on family incomes and jobs. University of Massachusetts Political Economy Research Institute.

Brauner, C., Wöhrmann, A. M., \& Michel, A. (2018). BAuA-Arbeitszeitbefragung: Arbeitszeitwünsche von Beschäftigten in Deutschland [BAuA working time survey: Working time wishes of employees in Germany]. Bundesanstalt für Arbeitsschutz und Arbeitsmedizin. doi: 10.21934/baua:bericht20181005

Bregman, R. (2017). Utopia for realists: And how we can get there. Bloomsbury Publishing.

Brynjolfsson, E., \& McAfee, A. (2014). The second machine age: Work, progress, and prosperity in a time of brilliant technologies. WW Norton \& Company.

Bunderson, J. S., \& Thompson, J. A. (2009). The call of the wild: Zookeepers, callings, and the double-edged sword of deeply meaningful work. Administrative Science Quarterly, 54, 32-57. doi: 10.2189/asqu.2009.54.1.32

Cacioppo, J. T., \& Hawkley, L. C. (2009). Perceived social isolation and cognition. Trends in Cognitive Sciences, 13, 447-454. doi: $10.1016 /$ j.tics.2009.06.005

Campos, F., Frese, M., Goldstein, M., Iacovone, L., Johnson, H. C., McKenzie, D., \& Mensmann, M. (2017). Teaching personal initiative beats traditional training in boosting small business in West Africa. Science, 357, 1287-1290. doi: $10.1126 /$ science.aan5329 
Card, D., \& Krueger, A. B. (2015). Myth and measurement: The new economics of the minimum wage (Twentieth-anniversary ed.) Princeton University Press.

Cartwright, S., \& Holmes, N. (2006). The meaning of work: The challenge of regaining employee engagement and reducing cynicism. Human Resource Management Review, 16, 199-208. doi: 10.1016/j.hrmr.2006.03.012

Cesarini, D., Lindqvist, E., Notowidigdo, M. J., \& Östling, R. (2017). The effect of wealth on individual and household labor supply: Evidence from Swedish lotteries. American Economic Review, 107, 3917-46. doi: 10.1257/aer.20151589

Charlier, J. (1848). Solution du problème social ou constitution humanitaire. Basée sur la loi naturelle, et précèdé de l'exposé des motifs. Chez tous les libraires du Royaume.

Charlier, J. (1893). La question sociale résolue précédée du testament philosophique d’u penseur. Weissenbruch.

Clark, A. E., \& Georgellis, Y. (2013). Back to baseline in Britain: Adaptation in the British household panel survey. Economica, 80, 496-512. doi: 10.1111/ecca.12007

Clark, G. (1986). Pakistan's Zakat and 'Ushr as a welfare system. In A. M. Weiss (Ed.), Islamic reassertion in Pakistan: The application of islamic laws in a modern state (pp. 79-95). Syracuse University Press.

Clinton, H. R. (2017). What happened. Simon and Schuster Paperbacks.

Cole, G. D. H. (1953). A history of socialist thought. Macmillan.

Colquitt, J. A., Conlon, D. E., Wesson, M. J., Porter, C. O. L. H., \& Ng, K. Y. (2001). Justice at the millennium: A metaanalytic review of 25 years of organizational justice research. Journal of Applied Psychology, 86, 425-445. doi: 10.1037/00219010.86.3.425

Cropanzano, R., Goldman, B., \& Folger, R. (2003). Deontic justice: The role of moral principles in workplace fairness. Journal of Organizational Behavior: The International Journal of Industrial, Occupational and Organizational Psychology and Behavior, 24, 1019-1024. doi: 10.1002/job.228

Cunliffe, J., \& Erreygers, G. (2001). The enigmatic legacy of Charles Fourier: Joseph Charlier and basic income. History of Political Economy, 33, 459-484. doi: 10.1215/00182702-33-3-459

de Voogt, A., \& Lang, J. W. (2017). Employee work ethic in nine nonindustrialized contexts: Some surprising non-POSH findings. Industrial and Organizational Psychology, 10, 398-403.

De Wispelaere, J. (2016). The struggle for strategy: On the politics of the basic income proposal. Politics, 36, 131-141. doi: 10. $1111 / 1467-9256.12102$

Deci, E. L., \& Ryan, R. M. (1985). Intrinsic motivation and self-determinaton in human behaviour. Plenum.

DePasquale, N., Sliwinski, M. J., Zarit, S. H., Buxton, O. M., \& Almeida, D. M. (2019). Unpaid caregiving roles and sleep among women working in nursing homes: A longitudinal study. Gerontologist, 59(3), 474-485. https://doi.org/10.1093/ geront/gnx185

Destatis. (2016). 35\% mehr Zeit für unbezahlte Arbeit als für Erwerbsarbeit [35\% more time for unpaid as compared with paid work]. https://www.destatis.de/Migration/ DE/ZahlenFakten/GesamtwirtschaftUmwelt/VGR/Haushaltsproduktion.html? $\mathrm{nn}=368502$

Douglas, C. H. (1924). Social credit. Eyre \& Spottiswoode Publishers.

Douglas, E. J., \& Shepherd, D. A. (2002). Self-employment as a career choice: Attitudes, entrepreneurial intentions, and utility maximization. Entrepreneurship Theory and Practice, 26, 81-90. doi: 10.1177/104225870202600305

Duboin, J. (1932). La grande relève des hommes par la machine. Fustier.

Duffy, R. D., Allan, B. A., England, J. W., Blustein, D. L., Autin, K. L., Douglass, R. P., \& Santos, E. J. R. (2017). The development and initial validation of the Decent Work Scale. Journal of Counseling Psychology, 64, 206-221. doi: 10.1037/ cou0000191

Duffy, R. D., Kim, H. J., Gensmer, N. P., Raque-Bogdan, T. L., Douglass, R. P., England, J. W., \& Buyukgoze-Kavas, A. (2019). Linking decent work with physical and mental health: A psychology of working perspective. Journal of Vocational Behavior, 112, 384-395. doi: 10.1016/j.jvb.2019.05.002

Duxbury, L., \& Done, G. (2015). Squeezed in the middle: Balancing paid employment, childcare and eldercare. In R. J. Burke, K. M. Page, \& C. L. Cooper (Eds.), Flourishing in life, work and careers: Individual wellbeing and career experiences (pp. 141-168). Edward Elgar.

Ekerdt, D. J. (1986). The busy ethic: Moral continuity between work and retirement. Gerontologist, 26(3), 239-244. doi: 10. 1093/geront/26.3.239

Elster, J. (1986). Comment on van der Veen and Van Parijs. Theory and Society, 15, 709-721. doi.org/10.1007/BF00239135

Erez, M. (2010). Culture and job design. Journal of Organizational Behavior, 31, 389-400. doi: 10.1002/job.651

Evans, D. K., \& Popova, A. (2014). Cash transfers and temptation goods: A review of global evidence. World Bank.

Fagan, C., \& Warren, T. (2001). Gender, employment and working time preferences in Europe. European Foundation for the Improvement of Living and Working Conditions.

Falk, P., \& Mäendpää, P. (1999). Hitting the jackpot: Lives of lottery millionaires. Berg.

Feldman, D. C., \& Bolino, M. C. (2000). Career patterns of the self-employed: Career motivations and career outcomes. Journal of Small Business Management, 38, 53-67.

Feldman, D. C., \& Ng, T. W. H. (2007). Careers: Mobility, embeddedness, and sucess. Journal of Management, 33, 350-377. doi: $10.1177 / 0149206307300815$ 
Flomenhoft, G. (2012). Applying the Alaska model in a resource-poor state: The example of Vermont. In K. Widerquist \& M. Howard (Eds.), Exporting the Alaska model: Adapting the permanent fund dividend for reform around the world (pp. 85107). Palgrave Macmillan.

Forget, E. L. (2011). The town with no poverty: The health effects of a Canadian guaranteed annual income field experiment. Canadian Public Policy, 37, 283-305. doi: 10.3138/cpp.37.3.283

Forget, E. L. (2018). Contemporary basic income experiments in historical context. In R. Benns \& J. Scheidler-Benns (Eds.), The poverty, inequality, and job challenge: The case for basic income in Canada (pp. 45-60). Maracle Press.

Fouad, N. A., \& Bynner, J. (2008). Work transitions. American Psychologist, 63, 241-251. doi: 10.1037/0003-066X.63.4.241

Fourier, C. (1967). La Fausse Industrie, morcelée, répugnante, mesongère, et l'antidote, l'industrie naturelle, combinée, attrayante, véridique, donnant quadruple produit et perfection extrème en toutes qualités. Anthropos. (Orginal work published in 1836)

Fourier, C. C. (1985). L'allocation universelle. La Revue Nouvelle, 41, 345-351.

Frese, M., \& Fay, D. (2001). Personal initiative (PI): An active performance concept for work in the 21st century. Research in Organizational Behavior, 23, 133-187. doi: 10.1016/S0191-3085(01)23005-6

Frese, M., Kring, W., Soose, A., \& Zempel, J. (1996). Personal initiative at work: Differences between East and West Germany. Academy of Management Journal, 39, 37-63. doi: 10.2307/256630

Frese, M., \& Zapf, D. (1994). Action as the core of work psychology: A German approach. In H. C. Triandis, M. D. Dunnette, \& L. Hough (Eds.), Handbook of industrial and organiza-tional psychology (Vol. 4, pp. 271-340). Consulting Psychologists Press.

Frey, C., \& Osborne, M. (2013). The future of employment. Oxford Martin School Paper, University of Oxford. http://sep4u. gr/wp-content/uploads/The_Future_of_Employment_ox_2013.pdf

Friedman, M. (1962). Capitalism and freedom. University of Chicago Press.

Friedman, M. (1968). The case for the negative income tax: A view from the right. In J. Bunzel (Ed.), Issues of American public policy (pp. 111-120). Prentice-Hall.

Furnham, A. (1984). The Protestant work ethic: A review of the psychological literature. European Journal of Social Psychology, 14, 87-104. doi: 10.1002/ejsp.2420140108

Gagné, M., \& Deci, E. L. (2005). Self-determination theory and work motivation. Journal of Organizational Behavior, 26, 331362. doi: $10.1002 /$ job. 322

Galbraith, J. K. (1969). The affluent society (2nd ed.). Hamish Hamilton.

Gallup. (2017). State of the global workplace. Gallup Press.

Give Directly. (2018). Basic income. https://givedirectly.org/ubi-study/

Goehler, A. (2017). Freiheit, Gleichheit, Grundeinkommen. (Liberty, equality, basic income). In P. Kovce (Ed.), Soziale Zukunft. Das bedingungslose Grundeinkommen. Die Debatte [Social future. The basic income. The debate] (pp. 42-48). Verlag Freies Geistesleben.

Gonzalez-Mulé, E., \& Cockburn, B. (2017). Worked to death: The relationships of job demands and job control with mortality. Personnel Psychology, 70, 73-112. doi: 10.1111/peps.12206

Graeber, D. (2018). Bullshit jobs. Simon \& Schuster.

Grant, A. M., \& Wall, T. D. (2009). The neglected science and art of quasi-experimentation. Organizational Research Methods, 12(4), 653-686. doi: 10.1177/1094428108320737

Greaves, C. E., Parker, S. L., Zacher, H., \& Jimmieson, N. L. (2015). Turnover intentions of employees with informal eldercare responsibilities: The role of core self-evaluations and supervisor support. International Journal of Aging and Human Development, 82, 79-115. doi: 10.1177/0091415015624418

Greaves, C. E., Parker, S. L., Zacher, H., \& Jimmieson, N. L. (2017). Working mothers' emotional exhaustion from work and care: The role of core self-evaluations, mental health, and control. Work \& Stress, 31, 164-181. doi: 10.1080/02678373.2017. 1303760

Griffin, B., \& Hesketh, B. (2008). Post-retirement at work: The individual determinants of paid and volunteer work. Journal of Occupational and Organizational Psychology, 81, 101-121. doi: 10.1348/096317907X202518

Grün, C., Hauser, W., \& Rhein, T. (2010). Is any job better than no job? Life satisfaction and re-employment. Journal of Labor Research, 31, 285-306. doi: 10.1007/s12122-010-9093-2

Haarmann, C., \& Haarmann, D. (2012). Namibia: Seeing the sun rise-The realities and hopes of the Basic Income Grant pilot project. In M. C. Murray \& C. Pateman (Eds.), Basic income worldwide (pp. 33-58). Palgrave Macmillan.

Hacker, W. (1986). Complete vs. incomplete working tasks-a concept and its verification. In G. Debus \& W. Schroiff (Eds.), The psychology of work organization (pp. 23-36). Elsevier.

Hacker, W. (1998). Allgemeine Arbeitspsychologie: Psychische Regulation von Arbeitstätig-keiten [General work psychology: Mental regulation of work tasks]. Huber.

Hacker, W. (2003). Action regulation theory: A practical tool for the design of modern work processes? European Journal of Work and Organizational Psychology, 12, 105-130. doi: 10.1080/13594320344000075 
Hackman, J. R., \& Oldham, G. R. (1976). Motivation through the design of work: Test of a theory. Organizational Behavior and Human Performance, 16, 250-279. doi: 10.1016/0030-5073(76)90016-7

Hammer, L. B., Colton, C. L., Caubet, S., \& Brockwood, K. B. (2002). The unbalanced life: Work and family conflict. In J. C. Thomas \& M. Hersen (Eds.), Handbook of mental health in the workplace (pp. 83-101). Sage.

Hanlon J., Barrientos, A., \& Hulme, D. (2010). Just give the money to the poor: The development revolution from the global south. Kumarian Press.

Hayek, F. A. (1986). The road to serfdom. Routledge and Kegan Paul. (Original work published 1944)

Healy, S., Murphy, M., \& Reynolds, B. (2013). Basic income: an instrument for transformation in the twenty-first century. Irish Journal of Sociology, 21, 116-130. doi: 10.7227/IJS.21.2.9

Hebl, M., Barron, L., Cox, C. B., \& Corrington, A. R. (2016). The efficacy of sexual orientation anti-discrimination legislation. Equality, Diversity and Inclusion: An International Journal, 35(7-8), 449-466. doi: 10.1108/EDI-07-2016-0060

Heckhausen, J., \& Heckhausen, H. (2008). Motivation and action. Cambridge University Press.

Hedenus, A. (2012). Who wants to work less? Significance of socio-economic status and work conditions for work commitment among Swedish lottery winners. Acta Sociologica, 55(4), 335-350. doi: 10.1177/0001699312460251

Herzberg, F., Mausner, B., \& Bloch Snyderman, B. (1959). The motivation to work. Transaction Publishers.

Hideg, I., Krstic, A., Trau, R. N., \& Zarina, T. (2018). The unintended consequences of maternity leaves: How agency interventions mitigate the negative effects of longer legislated maternity leaves. Journal of Applied Psychology, 103(10), 11551164. doi: $10.1037 /$ apl0000327

Higgins, E. T. (1997). Beyond pleasure and pain. American Psychologist, 52, 1280-1300.

Highhouse, S., Zickar, M. J., \& Yankelevich, M. (2010). Would you work if you won the lottery? Tracking changes in the American work ethic. Journal of Applied Psychology, 95(2), 349-357. doi: 10.1037/a0018359

Hirsch, D. (2015). Could a "citizen's income" work? Joseph Rowntree Foundation.

Hofstede, G. (1980). Motivation, leadership, and organization: Do American theories apply abroad? Organizational Dynamics, 9, 42-63. doi: 10.1016/0090-2616(80)90013-3

Holmes, A. (2016, May 11). Two thirds of Europeans for basic income-Dalia CEO presents surprising results in Zurich. https://daliaresearch.com/two-thirds-of-europeans-for-basic-income-dalia-ceo-presents-surprising-results-in-zurich/

Horvath, L. K., Grether, T., \& Wiese, B. S. (2018). Fathers' realizations of parental leave plans: Leadership responsibility as help or hindrance? Sex Roles, 79, 163-175. doi: 10.1007/s11199-017-0861-9

Hum, D., \& Simpson, W. (1993). Economic response to a guaranteed annual income: Experience from Canada and the United States. Journal of Labor Economics, 11(1), 263-296. doi: 10.1086/298335

International Labour Organization. (1999). Decent work: Report of the director-general to the 87th Session of the International Labour Conference. International Labour Office.

International Labour Organization. (2017). World social protection report 2017-19: Universal social protection to achieve the sustainable development goals. International Labour Office.

International Monetary Fund. (2017). Tackling inequality-fiscal monitor. International Monetary Fund.

Jackson, W. A. (1999). Basic income and the right to work: A Keynesian approach. Journal of Post Keynesian Economics, 21(4), 639-662. doi: 10.1080/01603477.1999.11490220

Jahoda, M. (1981). Work,employment, and unemployment: Values, theories, and approaches in social research. American Psychologist, 36, 184-191. doi: 10.1037/0003-066X.36.2.184

Jahoda, M. (1983). Employment and unemployment: A social-psychological analysis. Cambridge University Press.

Jongen, E., De Boer, H. W., \& Dekker, P. (2014). MICSIM-A behavioural microsimulation model for the analysis of taxbenefit reform in the Netherlands. CPB Background Document, 27.

Jordan, B. (1973). Paupers: The making of the new claiming class. Routledge \& Kegan Paul.

Jordan, B. (2011). The perils of basic income: Ambiguous opportunities for the implementation of a utopian proposal. Policy \& Politics, 39, 101-114. doi: 10.1332/030557311X546343

Judge, T. A., Parker, S., Colbert, A. E., Heller, D., \& Ilies, R. (2001). Job satisfaction: A cross-cultural review. In N. Anderson, D. S. Ones, H. K. Sinangil, \& C. Viswesvaran (Eds.), Handbook of industrial, work and organizational psychology (Vol. 2, pp. 25-52). Sage.

Judge, T. A., Piccolo, R. F., Podsakoff, N. P., Shaw, J. C., \& Rich, B. L. (2010). The relationship between pay and job satisfaction: A meta-analysis of the literature. Journal of Vocational Behavior, 77, 157-167. doi: 10.1016/j.jvb.2010.04.002

Kalleberg, A. L. (2008). The mismatched worker: When people don't fit their jobs. Academy of Management Perspectives, 22(1), 24-40. doi: 10.5465/amp.2008.31217510

Kalleberg, A. L., \& Mastekaasa, A. (2001). Satisfied movers, commited stayers: The impact of job mobility on work attitudes in Norway. Work and Occupations, 28(2), 183-209. doi: 10.1177/0730888401028002004

Keynes, J. M. (2010). Economic possibilities for our grandchildren. In Essays in persuasion. The collected writings (Vol. 9, pp. 321-332). Palgrave Macmillan. (Original work published 1933)

King, J. E., \& Marangos, J. (2006). Two arguments for basic income: Thomas Paine (1737-1809) and Thomas Spence (17501814). History of Economic Ideas, 14(1), 55-71. 
King. M. L. (1967). Where do we go from here: Chaos or community? Harper \& Row.

Kristof-Brown, A. L., Zimmerman, R. D., \& Johnson, E. C. (2005). Consequences of individuals' fit at work: A meta-analysis of person-job, person-organization, person-group, and person-supervisor fit. Personnel Psychology, 58, 281-342. doi: 10. 1111/j.1744-6570.2005.00672.x

Kuiper, J. P. (1975). Niet meer werken om den brode. In M. Van Gils (Ed.), Werken en niet-werken in een veranderende omgeving. Swets \& Zeitliger.

Lawler, E. E. (1971). Pay and organizational effectiveness. McGraw-Hill.

Leana, C. R., Mittal, V., \& Stiehl, E. (2012). Organizational behavior and the working poor. Organization Science, 23(3), 888906. doi: 10.1287 /orsc. 1110.0672

Lefkowitz, J. (2017). Ethics and values in industrial-organizational psychology. Taylor \& Francis.

LePine, J. A., Podsakoff, N. P., \& LePine, M. A. (2005). A meta-analytic test of the challenge stressor-hindrance stressor framework: An explanation for inconsistent relationships among stressors and performance. Academy of Management Journal, 48(5), 764-775. doi: 10.5465/amj.2005.18803921

LePine, J. A., \& Van Dyne, L. (1998). Predicting voice behavior in work groups. Journal of Applied Psychology, 83(6), 853868. doi: 10.1037/0021-9010.83.6.853

Lievens, F., Decaesteker, C., Coetsier, P., \& Geirnaert, J. (2001). Organizational attractiveness for prospective applicants: A person-organization fit perspective. Applied Psychology: An International Review, 50(1), 30-51. doi: 10.1111/1464-0597. 00047

Long, H. P. (1994). Share our wealth: Every man a king. In R. C. Byrd (Ed.), The Senate 1789-1989: Classic speeches 1830-1993 (Vol. 3, pp. 587-593). US Senate Historical Office. (Original work published 1934)

Lowrey, A. (2018). Give people money: How a universal basic income would end poverty, revolutionize work, and remake the world. Crown.

Lucas, R. E., Clark, A. E., Georgellis, Y., \& Diener, E. (2004). Unemployment alters the set point for life satisfaction. Psychological Science, 15, 8-13. doi: 10.1111/j.0963-7214.2004.01501002.x

Marinescu, I. (2018). No strings attached: The behavioral effects of U.S. unconditional cash transfer programs. National Bureau of Economic Research, Working paper 24337.

McGovern, G., \& Leontief, W. (1972, May 4). George McGovern: On taking and redistributing income. New York Review of Books.

McKay, A., \& Vanevery, J. (2000). Gender, family, and income maintenance: A feminist case for citizens basic income. Social Politics: International Studies in Gender, State \& Society, 7(2), 266-284. doi: 10.1093/sp/7.2.266

McKinsey Global Institute. (2015). The power of parity: How advancing women's equality can add $\$ 12$ trillion to global growth. https://www.mckinsey.com/ /media/McKinsey/Featured\%20Insights/Employment\%20and\%20Growth/How\% 20advancing\%20womens\%20equality\%20can\%20add\%2012\%20trillion\%20to\%20global\%20growth/MGI\%20Power\%20of \%20parity_Full\%20report_September\%202015.ashx

Metcalf, G. E. (1995). Value-added taxation: A tax whose time has come? Journal of Economic Perspectives, 9, 121-140. doi: 10. 1257/jep.9.1.121

Meyer, N. I., Petersen, K. H., \& Sørensen, V. (1978). Oprør fra midten. Gyldendal.

Mill, J. S. (1904). Principles of political economy. Longmans, Green \& Co. (Original work published 1848)

Milner, E. M., \& Milner, D. (1918). Scheme for a state bonus: A rational method of solving the social problem. Kent, Simpkin, Marshall \& Co.

Milner, D. (1920). Higher production by a bonus on national output: A proposal for a minimum income for all varying with national productivity. George Allen \& Unwin.

Miltenburg, J. (1989). Level schedules for mixed-model assembly lines in just-in-time production systems. Management Science, 35(2), 192-207. doi: 10.1287/mnsc.35.2.192

Miranda, V. (2011). Cooking, caring and volunteering: Unpaid work around the world. OECD Social, Employment and Migration, Working Paper 116. doi:10.1787/5kghrjm8s142-en

Mitschke, J. (1985). Steuer-und Transferordnung aus einem Guß. Entwurf einer Neugestaltung der direkten Steuern und Sozialtransfers in der Bundesrepublik Deutschland [A tax and transfer scheme from the same mould. Sketch of a new design of the direct taxes and social transfer in the Federal Republic of Germany]. Nomos Verlag.

Mor-Barak, M. E. (1995). The meaning of work for older adults seeking employment: The generativity factor. International Journal of Aging and Human Development, 41(4), 325-344. doi: 10.2190/VGTG-EPK6-Q4BH-Q67Q

More, T. (1978). Utopia. Penguin. (Original work published 1516)

Morse, N. C., \& Weiss, R. S. (1955). The function and meaning of work and the job. American Sociological Review, 20(2), 191-198. doi: $10.2307 / 2088325$

Mumby, D. K. (2019). Work: What is it good for? (Absolutely nothing): A critical theorist's perspective. Industrial and Organizational Psychology: Perspectives on Science and Practice, 12(4), 429-443. doi: 10.1017/iop.2019.69

Murray, C. 2008. Guaranteed income as a replacement for the welfare state. Basic Income Studies, 3(2), Article 6. doi: 10.2202/ 1932-0183.1115 
Ng, T. W. H., Sorensen, K. L., Eby, L. T., \& Feldman, D. C. (2007). Determinants of job mobility: A theoretical integration and extension. Journal of Occupational and Organizational Psychology, 80, 363-386. doi: 10.1348/096317906X130582

Nooteboom, B. (1987). Basic income as a basis for small business. International Small Business Journal, 5(3), 10-18. doi: 10. $1177 / 026624268700500301$

Organisation for Economic Co-operation and Development. (2017). Basic income as a policy option: Can it add up? [Policy Brief on the Future of Work]. Paris.

Orloff, A. S. (2013). Why basic income does not promote gender equality. In K. Widerquist, J. A. Noguera, Y. Vanderborght, \& J. De Wispelaere (Eds.), Basic income: An anthology of contemporary research (pp. 149-152). Wiley.

Ortiz, I., Behrendt, C., Acuña-Ulate, A., \& Anh, N. Q. (2018). Universal Basic Income proposals in light of ILO standards: Key issues and global costing. Extension of Social Security, Working Paper 62. International Labour Organization.

Paine, T. (1974). Agrarian justice. In P. S. Foner (Ed.), The life and major writings of Thomas Paine (pp. 605-623). Citadel Press. (Original work published 1796)

Paul, K. I., \& Batinic, B. (2010). The need for work: Jahoda's latent functions of employment in a representative sample of the German population. Journal of Organizational Behavior, 31(1), 45-64. doi: 10.1002/job.622

Paul, K. I., \& Moser, K. (2009). Unemployment impairs mental health: Meta-analyses. Journal of Vocational Behavior, 74(3), 264-282. doi: 10.1016/j.jvb.2009.01.001

Paulsen, R. (2008). Economically forced to work: A critical reconsideration of the lottery question. Basic Income Studies, 3(2), 1-20. doi: 10.2202/1932-0183.1104

Pigou, A. C. (1932). The economics of welfare. MacMillan. (Original work published in 1920)

Piketty, T. (1999). Allocation compensatrice de revenu ou revenu universel. In C. Robert, R. Godino, M. Jalmain, \& T. Piketty (Eds.), Pour une reforme du RMI (Vol. 104, pp. 21-30). Notes de La Fondation Saint-Simon.

Piketty, T. (2014). Capital in the twenty-first century. Harvard University Press.

Pinquart, M., \& Schindler, I. (2007). Changes of life satisfaction in the transition to retirement: A latent-class approach. Psychology and Aging, 22, 442-455. doi: 10.1037/0882-7974.22.3.442

Pinquart, M., \& Sörensen, S. (2003). Differences between caregivers and noncaregivers in psychological health and physical health: A meta-analysis. Psychology and Aging, 18(2), 250-267. doi: 10.1037/0882-7974.18.2.250

Popper-Lynkeus, J. (1912). Die allgemeine Nährpflicht als Lösung der sozialen Frage [The general plight to nourish as a solution to the social question]. Carl Reissner Verlag.

Principi, A., Schippers, J., Naegele, G., Di Rosa, M., \& Lamura, G. (2016). Understanding the link between older volunteers' resources and motivation to volunteer. Educational Gerontology, 42(2), 144-158. doi: 10.1080/03601277.2015.1083391

Quinn, M. (1994). Jeremy Bentham on the relief of indigence: An exercise in applied philosophy. Utilitas, 6(1), 81-96. doi: 10. $1017 /$ S0953820800001345

Rawls, J. (1988). The priority of right and ideas of the good. Philosophy \& Public Affairs, 17(4), 251-276.

Robeyns, I. (2001). Will a basic income do justice to women? Analyse \& Kritik, 22, 88-105. doi: 10.1515/auk-2001-0108

Robins, P. K. (1985). A comparison of the labor supply findings from the four negative income tax experiments. The Journal of Human Resources, 20(4), 567-82. doi: 10.2307/145685

Roosma, F., \& van Oorschot, W. (2020). Public opinion on basic income: Mapping European support for a radical alternative for welfare provision. Journal of European Social Policy, 30(2), 190-205. doi: 10.1177/0958928719882827

Rudolph, C. W., Allan, B., Clarke, M., Hertel, G., Hirschi, A., Kunze, F., Shockley, K., Shoss, M., Sonnentag, S., \& Zacher, H. (2020). Pandemics: Implications for research and practice in industrial and organizational psychology. Industrial and Organizational Psychology: Perspectives on Science and Practice, 14(1-2). https://doi.org/https://psyarxiv.com/k8us2

Russell, B. (1966). Roads to freedom: Socialism. anarchism, and syndicalism. Unwin Books. (Original work published 1918)

Russell, D. W. (1996). UCLA Loneliness Scale (Version 3): Reliability, validity, and factor structure. Journal of Personality Assessment, 66, 20-40. doi: 10.1207/s15327752jpa6601_2

Sacramento, C. A., Fay, D., \& West, M. A. (2013). Workplace duties or opportunities? Challenge stressors, regulatory focus, and creativity. Organizational Behavior and Human Decision Processes, 121(2), 141-157. doi: 10.1016/j.obhdp.2013.01.008

Saretsky, G. (1975, March 30-April 4). The John Henry effect: Potential confounder of experimental vs. control group approaches to the evaluation of educational innovations [Paper presentation]. Annual Meeting of the American Educational Research Association, Washington, DC.

Schildt, G. (2006). Das Sinken des Arbeitsvolumens im Industriezeitalter [The decline of the volume of labour in the Industrial Age]. Geschichte und Gesellschaft, 32, 119-148.

Schulz, P. (2017). Universal basic income in a feminist perspective and gender analysis. Global Social Policy, 17(1), 89-92. doi: $10.1177 / 1468018116686503$

Selenko, E., Batinic, B., \& Paul, K. (2011). Does latent deprivation lead to psychological distress? Investigating Jahoda's model in a four-wave study. Journal of Occupational and Organizational Psychology, 84(4), 723-740. doi: 10.1348/ 096317910X519360

Sen, A. (2001). Development as freedom. Oxford University Press.

Sennett, R. (2003). Respect in a world of inequality. Norton. 
Sibley, C. G., Greaves, L. M., Satherley, N., Wilson, M. S., Overall, N. C., Lee, C. H. J., Milojev, P., Bulbulia, J., Osborne, D., Milfont, T. L., Houkamau, C. A., Duck., I. M., Vickers-Jones, R., \& Barlow, F. K. (2020). Effects of the COVID-19 pandemic and nationwide lockdown on trust, attitudes towards government, and wellbeing. American Psychologist, 75(5), 618-630.

Smith, A. (2010). The wealth of nations: An inquiry into the nature and causes of the wealth of nations. Harriman House Limited. (Original work published 1776)

Smith, P. R. (2004). Elder care, gender, and work: The work-family issue of the 21st century. Berkeley Journal of Employment \& Labor Law, 25(2), 351-398.

Sonnentag, S., Venz, L., \& Casper, A. (2017). Advances in recovery research: What have we learned? What should be done next? Journal of Occupational Health Psychology, 22, 365-380. doi: 10.1037/ocp0000079

Spafford, J. (2013, December 8). Reconciling basic income and immigration. Metamorphoses and deformations. https:// jessespafford.tumblr.com/post/69381354548/reconciling-basic-income-and-immigration.

Spence, T. (2004). The rights of infants. In J. Cunliffe \& G. Erreygers (Eds.), Spence, the origins of universal grants (pp. 81-91). Palgrave MacMillan. (Original work published in 1797)

Standing, G. (2017). Basic income: And how we can make it happen. Penguin.

Stern, A. (2016). Raising the floor: How a universal basic income can renew our economy and rebuild the American Dream. Public Affairs.

Super, D. E. (1953). A theory of vocational development. American Psychologist, 8, 185-190. doi: 10.1037/h0056046

Tanner, M. (2015). The pros and cons of a guaranteed national income. Cato Institute.

Theobald, R. (1961). The challenge of abundance. Clarkson N. Potter.

Tinbergen, J. (1956). Economic policy: Principles and design. North Holland.

Tobin, J. (1966). The case for an income guarantee. Public Interest, 4, 31-41.

Tobin, J., Pechman, J. A., \& Mieszkowski, P. M. (1967). Is a negative income tax practical? Yale Law Journal, 77(1), 1-27. doi: 10.2307/795069

Torry, M. (2016). An evaluation of a strictly revenue neutral citizen's income scheme. EUROMOD, Working Paper EM5/16. https:/www.econstor.eu/bitstream/10419/197591/1/868838713.pdf

United Nations. (1948). Universal Declaration of Human Rights. https://www.un.org/en/universal-declaration-humanrights/

United Nations Conference on Trade and Development. (2017). Trade and development report 2017: Beyond austeritytowards a global new deal. https://unctad.org/system/files/official-document/tdr2017_en.pdf

Van der Hülst, M. (2003). Long work hours and health. Scandinavian Journal of Work Environment \& Health, 29(3), 171188. doi: $10.5271 /$ sjweh.720

Van Parijs, P., \& Vanderborght, Y. (2017). Basic income: A radical proposal for a free society and a sane economy. Harvard University Press.

Vanderborght, Y., \& Van Parijs, P. (2005). Ein Grundeinkommen für alle? Geschichte und Zukunft eines radikalen Vorschlags [A basic income for all? History and future of a radical proposal]. Campus Verlag.

Vives, J. L. (2010). De subventione pauperum. On the relief of the poor, or of human needs. In P. Spicker (Ed.), The origins of modern welfare (pp. 1-100). Peter Lang. (Original work published 1526)

Walker, C. R., \& Guest, R. H. (1952). The man on the assembly line. Harvard University Press.

Wang, M. (2007). Profiling retirees in the retirement transition and adjustment process: Examining the longitudinal change patterns of retirees' psychological well-being. Journal of Applied Psychology, 92(2), 455-474. doi: 10.1037/0021-9010.92.2. 455

Warr, P. B. (1982). A national study of non-financial employment commitment. Journal of Occupational Psychology, 55(4), 297-312. doi: 10.1111/j.2044-8325.1982.tb00103.x

Warr, P. B. (1987). Work, unemployment, and mental health. Oxford University Press.

Weber, M. (1905). The Protestant ethic and the spirit of capitalism and other writings. Penguin.

Werner, G. W. (2018). Einkommen für alle. Bedingungsloses Grundeinkomme-die Zeit ist reif [Income for all. Basic Income -the time is ripe]. Kiepenheuer \& Witsch.

Williams, M. L., McDaniel, M. A., \& Nguyen, N. T. (2006). A meta-analysis of the antecedents and consequences of pay level satisfaction. Journal of Applied Psychology, 91(2), 392-413. doi: 10.1037/0021-9010.91.2.392

World Economic Forum. (2018). The future of jobs report. http://www3.weforum.org/docs/WEF_Future_of_Jobs_2018.pdf

Wright, E. O. (2006). Basic income, stakeholder grants, and class analysis. In B. Ackerman, A. Alstott, \& P. Van Parijs (Eds.), Redesigning distribution: Basic income and stakeholder grants as alternative cornerstones for a more egalitarian capitalism. The real utopias project (Vol. 5, pp. 75-82). Verso.

Wrzesniewski, A., \& Dutton, J. E. (2001). Crafting a job: Revisioning employees as active crafters of their work. Academy of Management Review, 26(2), 179-201. doi: 10.5465/AMR.2001.4378011

Zacher, H., Hacker, W., \& Frese, M. (2016). Action regulation across the adult lifespan (ARAL): A meta-theory of work and aging. Work, Aging and Retirement, 2(3), 286-306. doi: 10.1093/workar/waw015 
Zamora, D. (2017, December 28). The case against a basic income. www.jacobinmag.com/2017/12/universal-basic-incomeinequality-work

Zwolinski, M. (2013, December 23). Why did Hayek support a basic income? http://www.libertarianism.org/columns/whydid-hayek-support-basic-income

Cite this article: Hüffmeier, J. and Zacher, H. (2021). The basic income: Initiating the needed discussion in industrial, work, and organizational psychology. Industrial and Organizational Psychology 14, 531-562. https://doi.org/10.1017/iop.2021.91 